\title{
DÜBLIN
}

Technological University Dublin

ARROW@TU Dublin

\section{Comparison of fungal spores concentrations measured with wideband integrated bioaerosol sensor and Hirst methodology}

\author{
S. Fernández-Rodríguez \\ Universidad de Extremadura \\ R. Tormo-Molina \\ Universidad de Extremadura
}

N. Lemonis

MeteoSwiss

See next page for additional authors

Follow this and additional works at: https://arrow.tudublin.ie/scschcpsart

Part of the Chemistry Commons, and the Environmental Sciences Commons

\section{Recommended Citation}

S. Fernández-Rodríguez, R. Tormo-Molina, N. Lemonis, B. Clot, D.J. O'Connor, John R. Sodeau, Comparison of fungal spores concentrations measured with wideband integrated bioaerosol sensor and Hirst methodology, Atmospheric Environment, Volume 175, 2018, Pages 1-14, ISSN 1352-2310, DOI:

10.1016/j.atmosenv.2017.11.038.

This Article is brought to you for free and open access by the School of Chemical and Pharmaceutical Sciences at ARROW@TU Dublin. It has been accepted for inclusion in Articles by an authorized administrator of ARROW@TU Dublin. For more information, please contact arrow.admin@tudublin.ie, aisling.coyne@tudublin.ie, gerard.connolly@tudublin.ie.

Funder: Junta de Extremadura (Spain); European Regional Development Fund, Research Group Fund

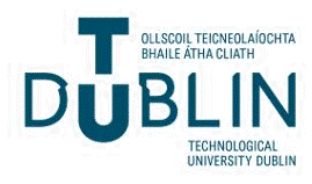


Authors

S. Fernández-Rodríguez, R. Tormo-Molina, N. Lemonis, B. Clot, David O'Connor, and John R. Sodeau

This article is available at ARROW@TU Dublin: https://arrow.tudublin.ie/scschcpsart/120 


\title{
Comparison of fungal spores concentrations measured with wideband integrated bioaerosol sensor and Hirst methodology
}

\author{
S. Fernández-Rodríguez ${ }^{\mathrm{a}, *}$, R. Tormo-Molina ${ }^{\mathrm{b}}$, N. Lemonis ${ }^{\mathrm{c}}$, B. Clot $^{\mathrm{c}}$, D.J. O'Connor ${ }^{\mathrm{d}, \mathrm{e}}$, \\ John R. Sodeau ${ }^{\mathrm{d}}$

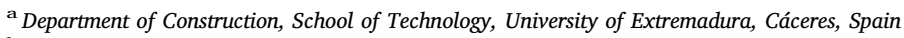 \\ ${ }^{\mathrm{b}}$ Department of Plant Biology, Ecology and Earth Sciences, Faculty of Science, Badajoz, University of Extremadura, Spain \\ ${ }^{\mathrm{c}}$ Federal Office of Meteorology and Climatology MeteoSwiss, Payerne, Switzerland \\ ${ }^{\mathrm{d}}$ Department of Chemistry and Environmental Research Institute, University College Cork, Ireland \\ e School of Chemical and Pharmaceutical Sciences, Dublin Institute of Technology, Dublin, Ireland
}

\section{A R T I C L E I N F O}

\section{Keywords:}

Airborne spores

Meteorology

Real-time fluorescence monitoring

Microscopy

\begin{abstract}
A B S T R A C T
The aim of this work was to provide both a comparison of traditional and novel methodologies for airborne spores detection (i.e. the Hirst Burkard trap and WIBS-4) and the first quantitative study of airborne fungal concentrations in Payerne (Western Switzerland) as well as their relation to meteorological parameters. From the traditional method -Hirst trap and microscope analysis-, sixty-three propagule types (spores, sporangia and hyphae) were identified and the average spore concentrations measured over the full period amounted to $4145 \pm 263.0$ spores $/ \mathrm{m}^{3}$. Maximum values were reached on July 19th and on August 6th. Twenty-six spore types reached average levels above 10 spores $/ \mathrm{m}^{3}$. Airborne fungal propagules in Payerne showed a clear seasonal pattern, increasing from low values in early spring to maxima in summer. Daily average concentrations above 5000 spores $/ \mathrm{m}^{3}$ were almost constant in summer from mid-June onwards. Weather parameters showed a relevant role for determining the observed spore concentrations. Coniferous forest, dominant in the surroundings, may be a relevant source for airborne fungal propagules as their distribution and predominant wind directions are consistent with the origin. The comparison between the two methodologies used in this campaign showed remarkably consistent patterns throughout the campaign. A correlation coefficient of 0.9 (CI 0.76-0.96) was seen between the two over the time period for daily resolutions (Hirst trap and WIBS-4). This apparent colinearity was seen to fall away once increased resolution was employed. However at higher resolutions upon removal of Cladosporium species from the total fungal concentrations (Hirst trap), an increased correlation coefficient was again noted between the two instruments $(\mathrm{R}=0.81$ with confidence intervals of 0.74 and 0.86$)$.
\end{abstract}

\section{Introduction}

Airborne fungal spores represent the major fraction of the particulates termed Primary Biological Aerosol Particles (PBAPs) found in the atmosphere (Ansari et al., 2015). Their quantification is important because it is widely accepted that fungal spores play an important role in the health of humans, animals and plants. In addition, fungal spores and bacteria have been seen to act as "seeds" for the growth of Ice Nuclei (IN) (Haga et al., 2014). However, several recent reports have also highlighted the effect of climate change on the abundance and temporal trends of fungal spores found in a variety of regions, e.g.: UK and Spain (Vélez-Pereira et al., 2016). Current knowledge has been summarised in a review (Salonen et al., 2015). The dispersion of fungal spores is influenced by meteorological conditions (Filali Ben Sidel et al., 2015;
Grinn-Gofroń and Bosiacka, 2015; Grinn-Gofroń et al., 2016; Hernández Trejo et al., 2013; Pakpour et al., 2015) and their impacts on human health can be experienced at great distances from the sources (Fernández-Rodríguez et al., 2015).

The four genera most commonly associated with the development of allergy are Alternaria, Cladosporium, Penicillium and Aspergillus (Twaroch et al., 2015). The first two make a large contribution to the fungal spore load in continental climates. (Corden et al., 2003; GrinnGofroń and Rapiejko, 2009; Grinn-Gofroń et al., 2016). However in Mediterranean regions, all four are abundant (El-Akhdar and Ouda, 2009; Fernández-Rodríguez et al., 2014; Lanier et al., 2010; Pasquarella et al., 2015; Pepeljnjak and Klarić, 2005; Pyrri and Kapsanaki-Gotsi, 2015; Rodolfi et al., 2003). Waste processing activities such as composting/green waste activities can also affect the number

\footnotetext{
* Corresponding author. Tel.: + 34927 257000; fax: +34 927257002.

E-mail address: santiferro@unex.es (S. Fernández-Rodríguez).
} 
Table 1

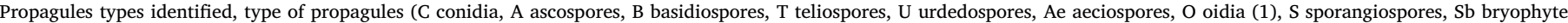
spores, $\mathrm{M}$ spores of Myxomycetes, $\mathrm{H}$ hyphae), peak of concentration and average concentration in propagules per cubic meter. Note: Sb are not fungal propagules.

\begin{tabular}{|c|c|c|c|c|c|c|c|}
\hline Name & type & Peak & Prop. $/ \mathrm{m}^{3}$ & Name & type & Peak & Prop. $/ \mathrm{m}^{3}$ \\
\hline Abortiporus & $\mathrm{B}$ & 822.1 & 53.3 & Massaria & A & 150.3 & 13.1 \\
\hline Aeciospores & $\mathrm{Ae}$ & 17.7 & 1.5 & Melanomma & $\mathrm{A}$ & 35.4 & 3.3 \\
\hline Agrocybe & $\mathrm{B}$ & 349.2 & 63.3 & Myxomycetes & M & 66.3 & 8.4 \\
\hline Alternaria & $\mathrm{C}$ & 742.6 & 35.3 & Neurospora & $\mathrm{C}$ & 8.8 & 0.4 \\
\hline Amanita & $\mathrm{B}$ & 632.1 & 49.6 & Nigrospore & $\mathrm{C}$ & 70.7 & 1.4 \\
\hline Arthrinium & $\mathrm{C}$ & 44.2 & 3.6 & Not identified & NI & 185.6 & 15.0 \\
\hline Ascospores & A & 75.1 & 10.9 & Oidium & $\mathrm{O}$ & 17.7 & 1.1 \\
\hline Aspergillus-Penicillium & C & 353.6 & 82.0 & Paraphaerosphaeria & A & 79.6 & 6.9 \\
\hline Basidiospores & B & 247.5 & 28.3 & Periconia & C & 70.7 & 2.8 \\
\hline Botrytis & $\mathrm{C}$ & 238.7 & 30.1 & Peronospora & $\mathrm{S}$ & 30.9 & 4.2 \\
\hline Bovista & B & 22.1 & 1.5 & Pithomyces & $\mathrm{C}$ & 39.8 & 4.2 \\
\hline Bryophytes & $\mathrm{Sb}$ & 57.5 & 3.5 & Pleospora & A & 70.7 & 6.7 \\
\hline Cercospora & $\mathrm{C}$ & 61.9 & 6.0 & Polythrincium & $\mathrm{C}$ & 39.8 & 3.0 \\
\hline Cerebella-Monodyctis & $\mathrm{C}$ & 48.6 & 5.1 & Puccinia & $\mathrm{T}$ & 22.1 & 1.4 \\
\hline Chaetomium & A & 1060.8 & 12.0 & Scleroderma & B & 13.3 & 0.7 \\
\hline Cladosporium cladosporioides & $\mathrm{C}$ & 10236.7 & 809.4 & Spegazzinia & $\mathrm{C}$ & 4.4 & 0.0 \\
\hline Cladosporium herbarum & $\mathrm{C}$ & 16751.8 & 1941.2 & Sporopormiella & A & 4.4 & 0.0 \\
\hline Coprinus & B & 1052.0 & 207.8 & Stachybotrys & $\mathrm{C}$ & 207.7 & 1.6 \\
\hline Cortinarius & B & 22.1 & 2.2 & Stemphyllium & $\mathrm{C}$ & 35.4 & 2.9 \\
\hline Curvularia & $\mathrm{C}$ & 61.9 & 5.3 & Telephora & B & 35.4 & 3.9 \\
\hline Diatrypaceae & A & 455.3 & 17.1 & Tiletia & $\mathrm{T}$ & 194.5 & 6.2 \\
\hline Didymella & A & 238.7 & 20.7 & Torula & $\mathrm{C}$ & 39.8 & 5.2 \\
\hline Drechslera & $\mathrm{C}$ & 119.3 & 12.5 & Triposporium & $\mathrm{C}$ & 13.3 & 0.3 \\
\hline Emericella & A & 8.8 & 0.1 & Ulocladium & $\mathrm{C}$ & 22.1 & 2.0 \\
\hline Entoloma & B & 17.7 & 0.8 & Uredospora & $\mathrm{U}$ & 22.1 & 2.2 \\
\hline Epicoccum & $\mathrm{C}$ & 490.6 & 20.3 & Ustilago cynodontis & $\mathrm{T}$ & 84.0 & 6.4 \\
\hline Ganoderma & B & 596.7 & 106.6 & Ustilago maydis & $\mathrm{T}$ & 305.0 & 15.2 \\
\hline Helicomyces & $\mathrm{C}$ & 185.6 & 7.6 & Venturia & A & 9657.7 & 182.7 \\
\hline Hyphae & $\mathrm{H}$ & 229.8 & 32.8 & Venturia (hyaline) & A & 490.6 & 34.5 \\
\hline Leptosphaeria & $\mathrm{A}$ & 1547.0 & 128.4 & Xanthoria & A & 101.7 & 2.8 \\
\hline Leptosphaeria (hyaline) & A & 901.7 & 102.4 & Xylaria & $\mathrm{A}$ & 35.4 & 2.7 \\
\hline Lycoperdon & B & 53.0 & 2.6 & & & & \\
\hline
\end{tabular}

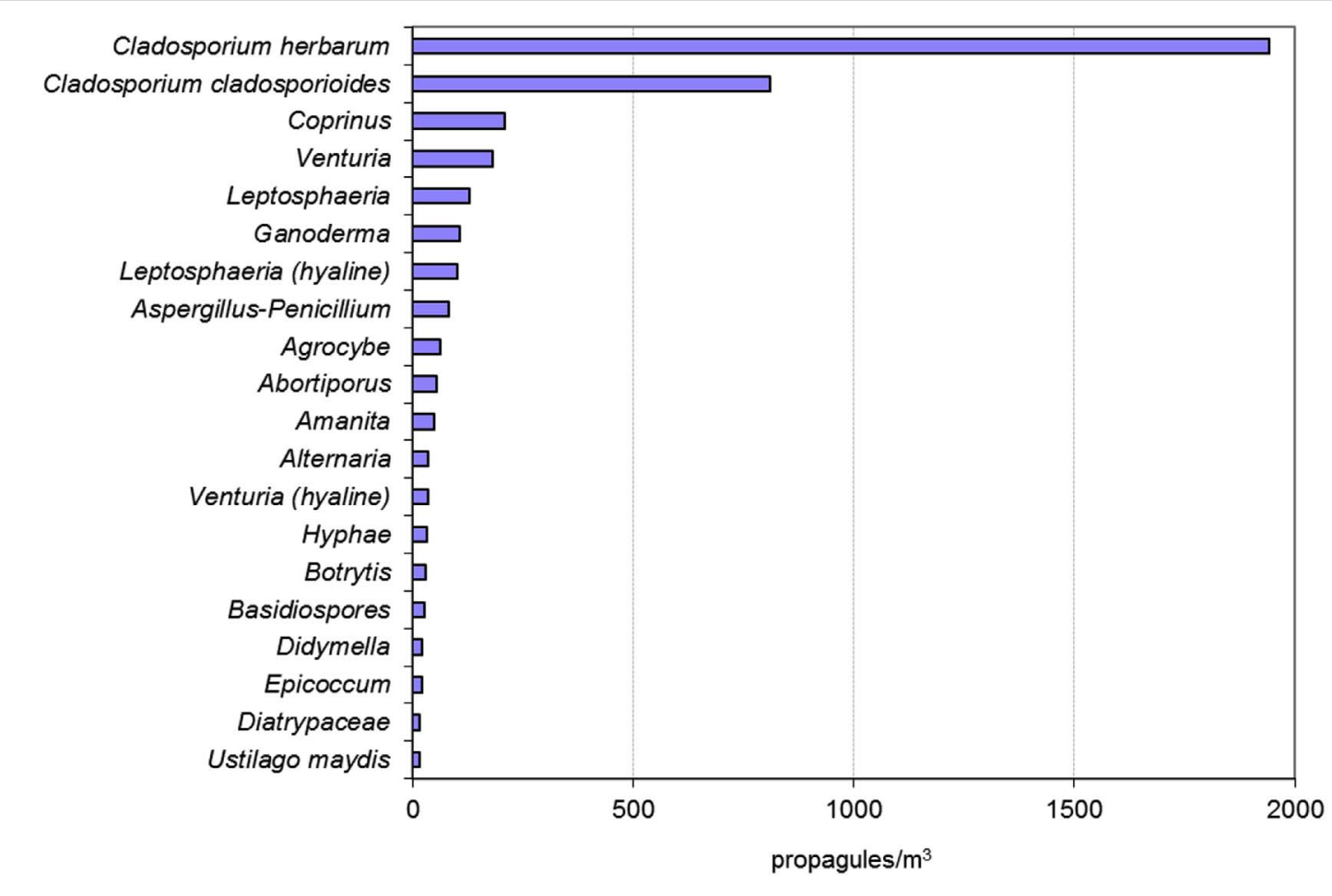

Fig. 1. Average concentration in propagules $/ \mathrm{m}^{3}$ for the whole period studied and the 20 propagules types more abundant. 

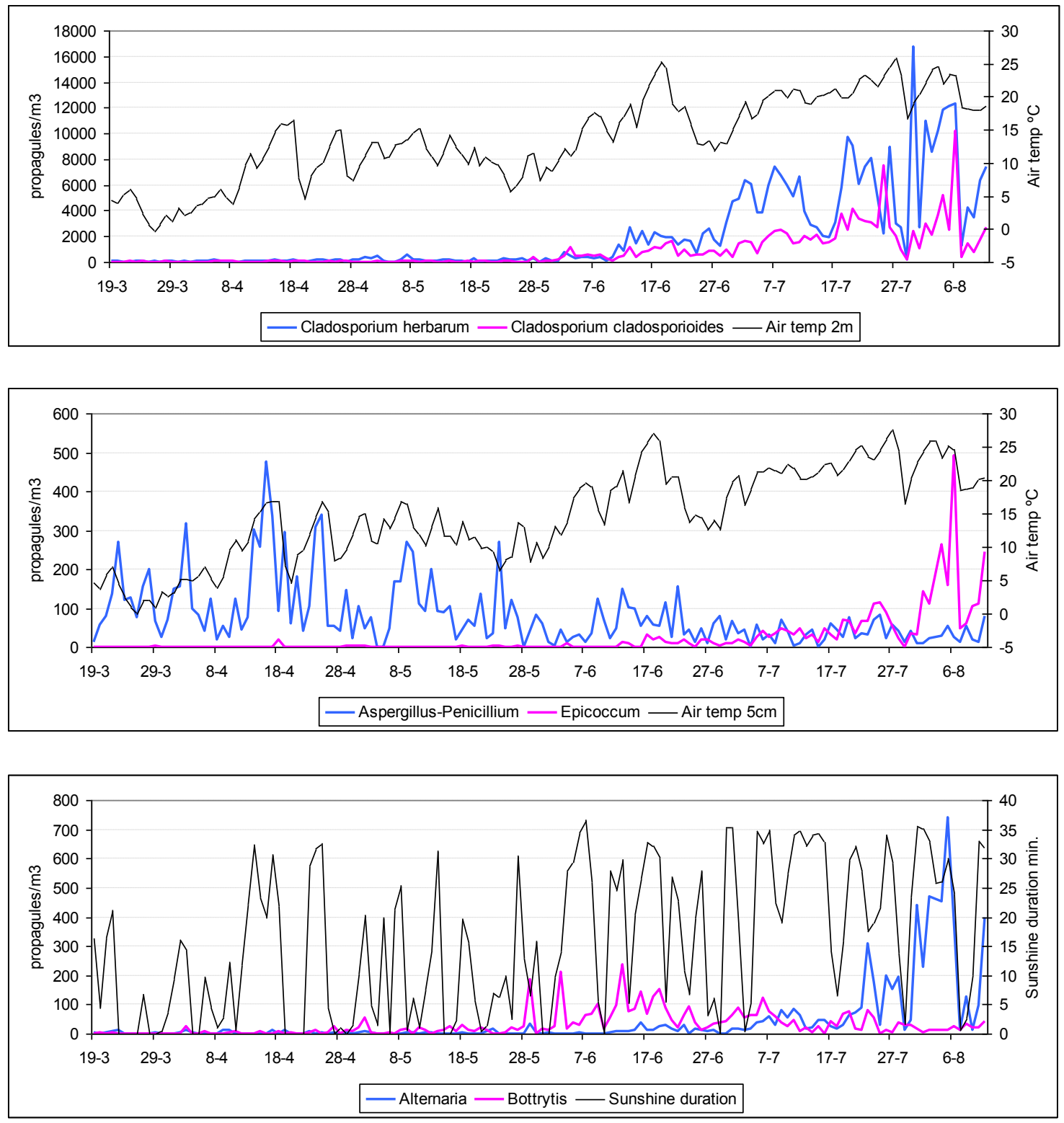

Fig. 2. Daily concentration for the conidia types more abundant and some meteorological parameters.

concentrations and types of spore identifiable in the air (Lanier et al., 2010; O'Connor et al., 2014), which can have occupational outcomes.

Airborne concentration data for pollen have also been obtained over many years (Leuschner, 1974; Leuschner and Boehm, 1981). For example in Switzerland, the location of the current study, results have been obtained at Basel, Davos, Locarno-Monti, Neuchâtel, Payerne and Zurich (Clot, 2001, 2003; Frei et al., 1995; Leuschner; Leuschner et al., 2000; Schäppi et al., 1996). Indeed some specific pollen types found there have been investigated in depth: hazel, birch and grasses (Clot, 1998, 2001; Frei, 1998; Frei and Leuschner, 2000). There have been fewer published reports on the numbers and types of airborne fungal spores present outdoors in Switzerland (Corbaz, 1968; Davies, 1969; Gubler et al., 1994; Varonier, 1969) although some studies have been performed indoors (Oberle et al., 2015) and indoors/outdoors (Flückiger et al., 2000).

In contrast, there are many reports of fungal spore levels and their characterization throughout Europe at a variety of locations. For example in France (Leyronas et al., 2015; Sindt et al., 2016), Italy (Tomassetti et al., 2013), Spain (Docampo et al., 2011; FernándezRodríguez et al., 2014, 2015; Hernández Trejo et al., 2013), Ireland
(O'Connor et al., 2014), UK (O'Connor et al., 2014), Portugal (Oliveira et al., 2009) and Greece (Pyrri and Kapsanaki-Gotsi, 2015).

Levels of fungal spores can be quantified, with the most used techniques, through growing or culturable and not growing or culturable methods (Fernández-Rodríguez et al., 2014; Pasquarella et al., 2015) and their atmospheric dispersion can now be computed using appropriate model simulations (Ansari et al., 2015), forecasting methodologies (Sadyś et al., 2016) and back trajectories of air masses (Fernández-Rodríguez et al., 2015). These approaches have been developed to serve as potential early warning tools for sensitized allergysufferers (Aira et al., 2013) as well as asthmatics because airborne fungi are considered to be a health risk by the World Health Organization (2000). Spores can also cause several problems on inorganic (Ruga et al., 2015; Sun et al., 2015) and organic (Akhtar et al., 2015; Kim et al., 2015; Muñoz-Rodríguez et al., 2010) surfaces such as museum artefacts and building fascia.

Whilst a number of campaigns and research groups have utilized impaction/optical microscopy to ascertain the number-concentrations of PBAP in the air there is a growing cohort of researchers that use novel fluorescent spectrometers as a means by which to count and 

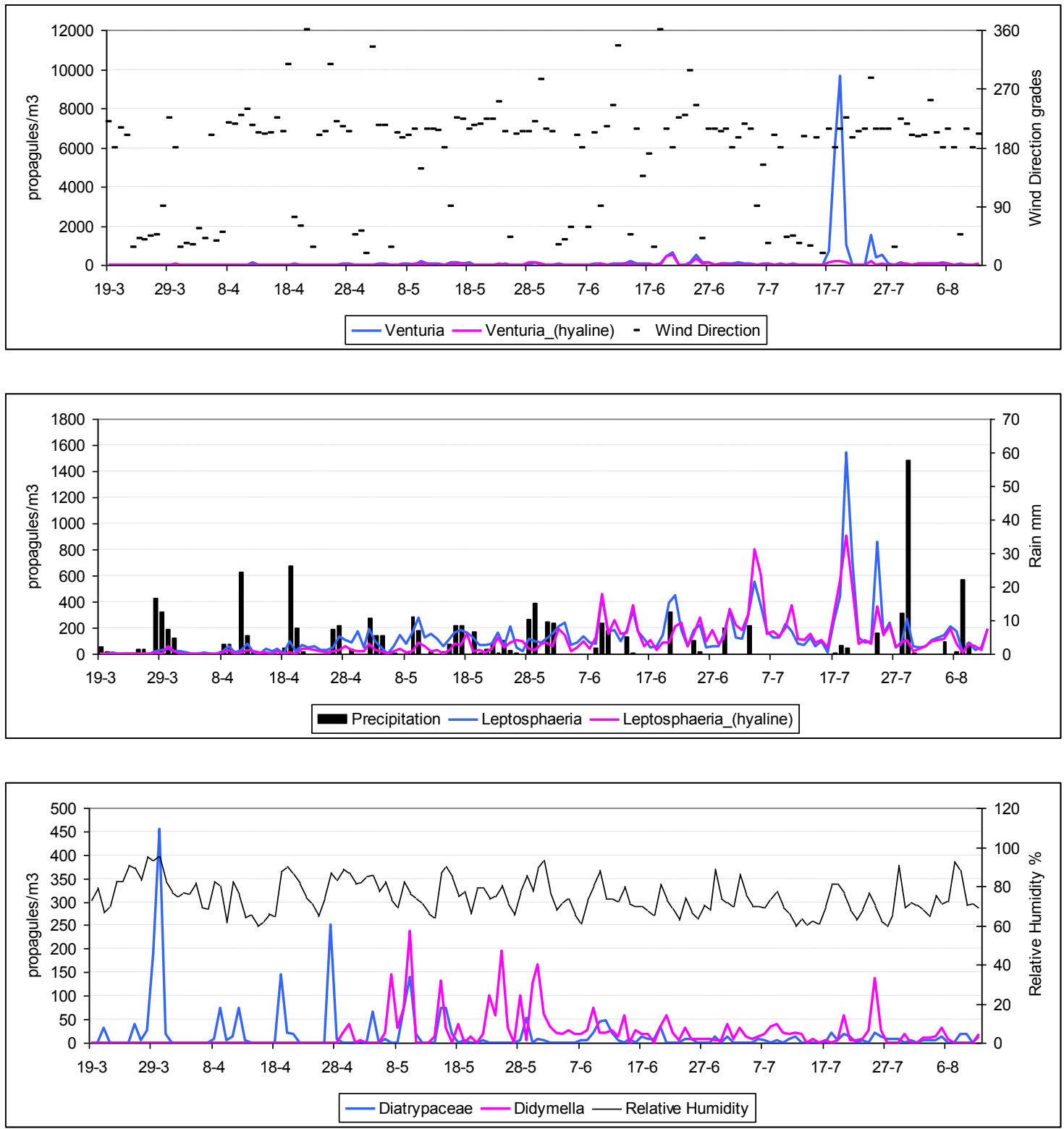

Fig. 3. Daily concentration for the ascospores types more abundant and some meteorological parameters.

identify such particles, in real-time. On-line (real-time) instruments based on fluorescence detection and particle sizing by optical scatter have been increasingly used in the evaluation of airborne concentrations of "FAP" (Fluorescent Aerosol Particles), where the term represents the portion of total particles measured that fluoresce. Two of the most often employed instruments are: (i) the UltraVioletAerodynamic Particle Sizer (UV-APS); (ii) WIBS (Wideband Integrated Bioaerosol Sensor Droplet measurement Technologies). The former has been used on a number of field campaigns including those set in the pristine environment associated with the central Amazon Basin as well as in urban settings in Europe (Huffman et al., 2010, 2012). Mean FAP number concentrations were measured to be $9.3 \times 10^{4} \mathrm{~m}^{-3}$ in the Amazon region while in Mainz, Germany ca. $3 \times 10^{3} \mathrm{~m}^{-3}$ particles were monitored i.e. levels that represent a significant and expected difference in magnitude. The majority of measurements made during both studies showed that increased concentrations of FAP were monitored during the periods 00:00-08:00 and 18:00-24:00, in line with them being of fungal origin (Huffman et al., 2010, 2012). Such increases in concentration were likely due to microclimatic conditions and factors such as relative humidity, temperature and light.
Only two reported studies compare results obtained from the realtime instruments with the more traditional impaction/optical microscopy methodologies. They were both performed in Ireland, and each campaign was relatively short by Healy et al. (Healy et al., 2014; O'Connor et al., 2015). Good number count co-linearity for the spores was obtained using the two approaches even though they operate using vastly different principles. However, insufficient comparative studies have been carried out so far to assess the use and reliability of the fluorescence-based instruments for informing aerobiological models. Furthermore, because so few studies have been carried out, the fluorescent behaviour of important airborne fungal spores such as Cladosporium spp is currently difficult to assess. Therefore, in order to improve our understanding of the reliability of the real-time technique for counting and identifying PBAP, the current campaign was mounted to investigate the levels and types of airborne fungal spores that were present in Payerne (W Switzerland).

The results provide a combination of data relating to fungal spores number concentrations in Payerne obtained by both a conventional Hirst Trap and a novel single particle fluorescence spectrometer (WIBS4). Statistical analysis was used to determine the trends apparent with 

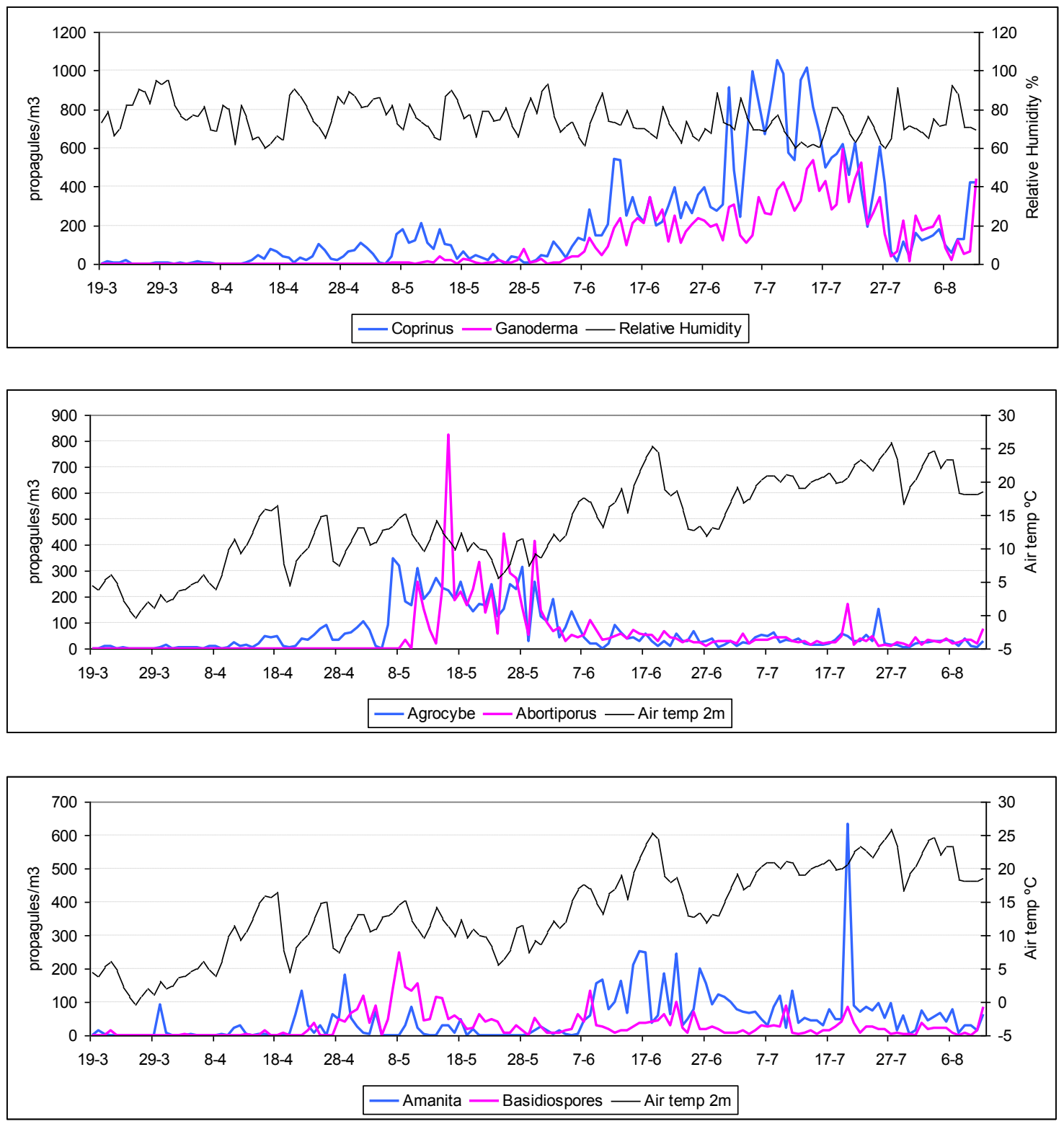

Fig. 4. Daily concentration for the basidiospores types more abundant and some meteorological parameters.

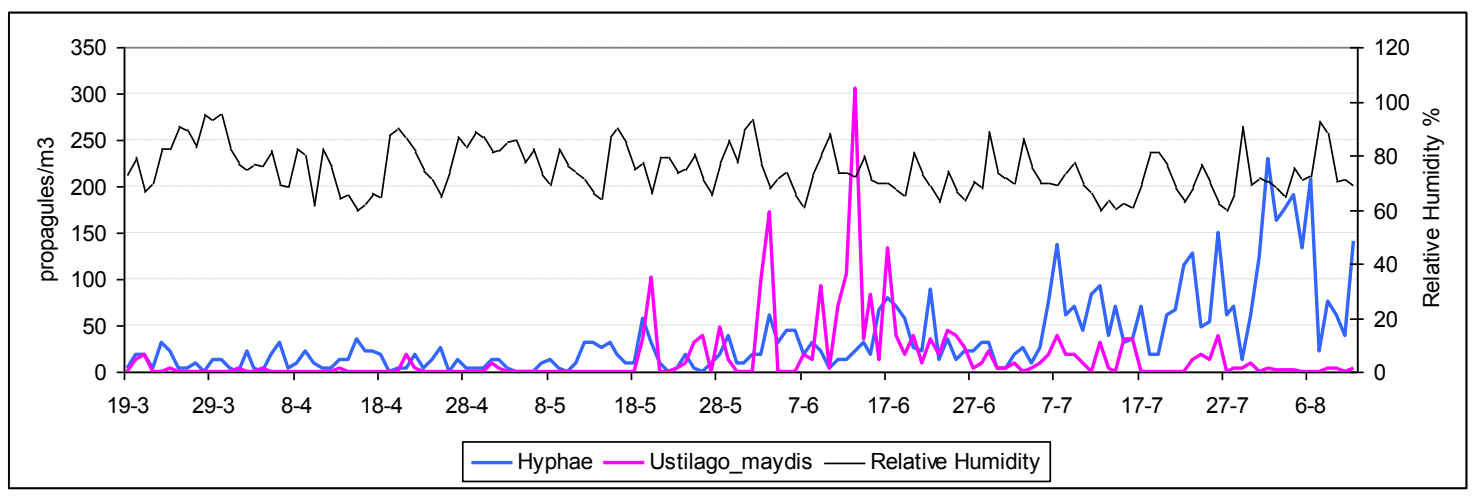

Fig. 5. Daily concentration for the hyphae and some meteorological parameters. 

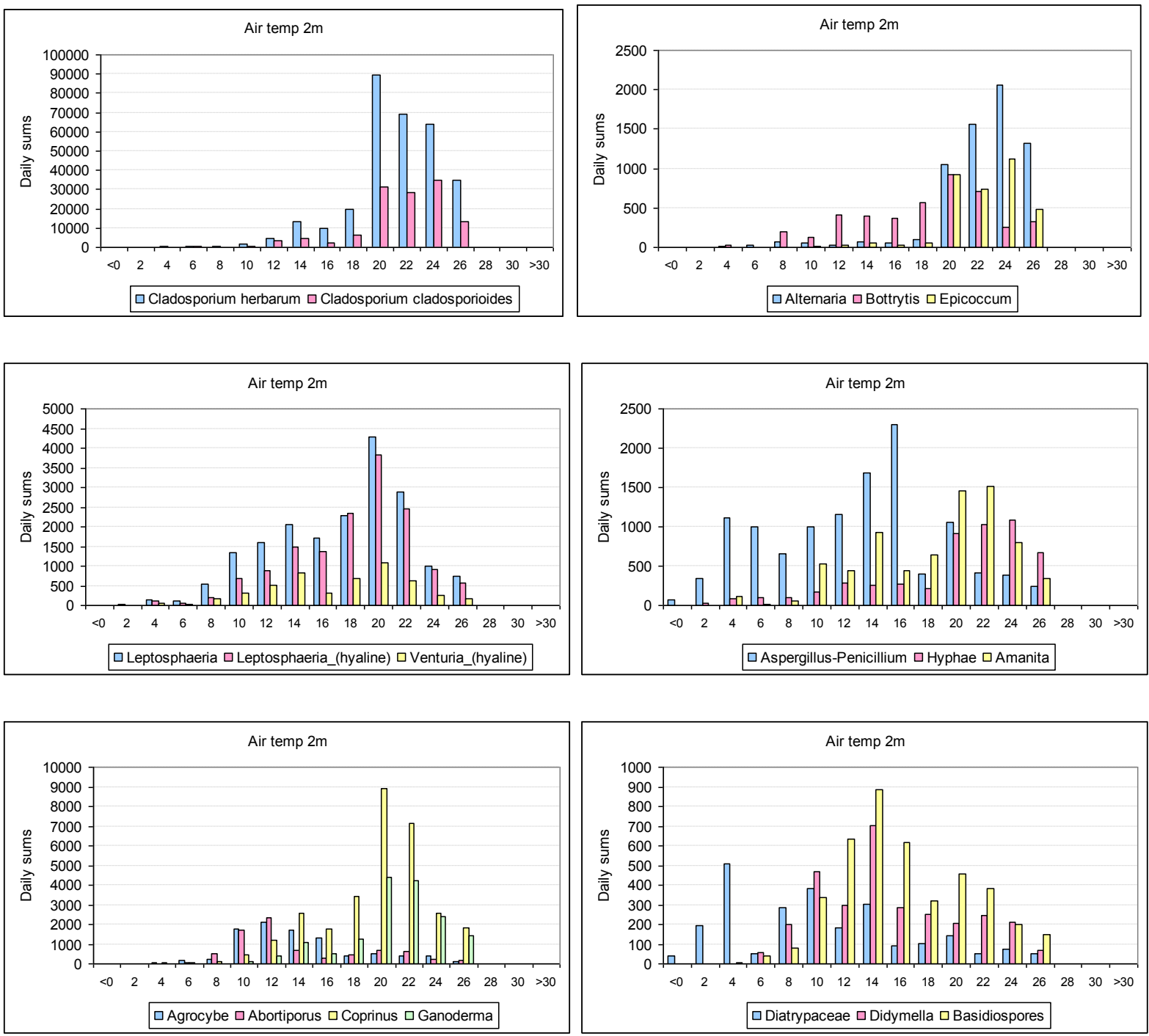

Fig. 6. Accumulated daily concentrations with respect to temperature intervals each two grades centigrade. Propagules types selected when significant correlation was obtained.

meteorological measurements and the findings are compared to those found in other parts of Europe.

\section{Materials and methods}

Sampling was performed between March 3rd and August 8th, 2013. A Hirst-type volumetric spore trap was located on the roof of the MeteoSwiss two-storey building in Payerne (Switzerland), which is a mainly rural site $\left(46^{\circ} 48^{\prime} 48^{\prime \prime} \mathrm{N}, 6^{\circ} 56^{\prime} 35^{\prime \prime} \mathrm{E}\right.$, Altitude 490 masl). The city is located $456 \mathrm{~m}$ above sea-level in the west part of Switzerland $\left(46^{\circ} 49^{\prime} \mathrm{N}\right.$ $\left.6^{\circ} 56^{\prime} \mathrm{E}\right)$ and is close to Lac Neuchâtel. The population comprises $\sim 10,000$ inhabitants and land-uses there include arable (60\%), forest (15\%) and pastures (7\%). Normal climatic values (1981-2010) provide an annual average temperature of $9.4{ }^{\circ} \mathrm{C}$ (January being the coldest month with $0.3{ }^{\circ} \mathrm{C}$ and July the hottest with $18.9{ }^{\circ} \mathrm{C}$ ) with total precipitation $(891 \mathrm{~mm})$ distributed over 114 days. August is the wettest month with $95 \mathrm{~mm}$ rain on average whereas February, at $47 \mathrm{~mm}$, is the driest.

The adhesive used was silicone and spore counting was performed at $\times 1000$ magnification with one horizontal (longitudinal) transect in the centre of the slide ( $0.2 \mathrm{~mm}$ diameter of LM field). This $\times 1000 \mathrm{LM}$ magnification used is necessary to identify and count small and hyaline spores with precision and accuracy. Data were provided as daily or hourly spore concentrations per cubic meter. It was observed that spore trapping failed for three days ( $2^{\text {nd }}-4$ th August 2013). The volumetric units generally employed were propagules $/ \mathrm{m}^{3}$, that includes spores and hyphae, although when no hyphae were included the term spores $/ \mathrm{m}^{3}$ was used.

Propagule types were characterized using group names in most cases (e.g. basidiospores, ascospores, teliospores, uredospores, aeciospores, spores of Byrophytes). Cladosporium cladosporioides and Cladosporium herbarum types were also counted. Hyphae were also counted and it should be noted that each propagule type likely includes different taxa.

Meteorological data were supplied by MeteoSwiss in Payerne (Switzerland). Meteorological parameters used were pressure (hPa or $\mathrm{mb})$, relative humidity $(\% \mathrm{RH})$, wind speed $(\mathrm{m} / \mathrm{s})$, wind direction (grades), global radiation $\left(\mathrm{w} / \mathrm{m}^{2}\right)$, air temperature at $2 \mathrm{~m}\left({ }^{\circ} \mathrm{C}\right)$, air temperature at $0.05 \mathrm{~m}\left({ }^{\circ} \mathrm{C}\right)$, precipitation $(\mathrm{mm})$, sunshine duration (hours).

Daily data were used as a basis for the analysis of the non-parametric correlations which were identified to exist between propagule concentrations and weather parameters $(\mathrm{n}=143)$ (Domínguez et al., 1992; Grinn-Gofroń and Bosiacka, 2012; Irdi et al., 2010). To assess the weather conditions associated with propagule releases into the air, the main meteorological parameters were categorized and the daily sums of propagule concentrations were calculated. The figures for daily data include only the weather parameters exhibiting the most statistically 

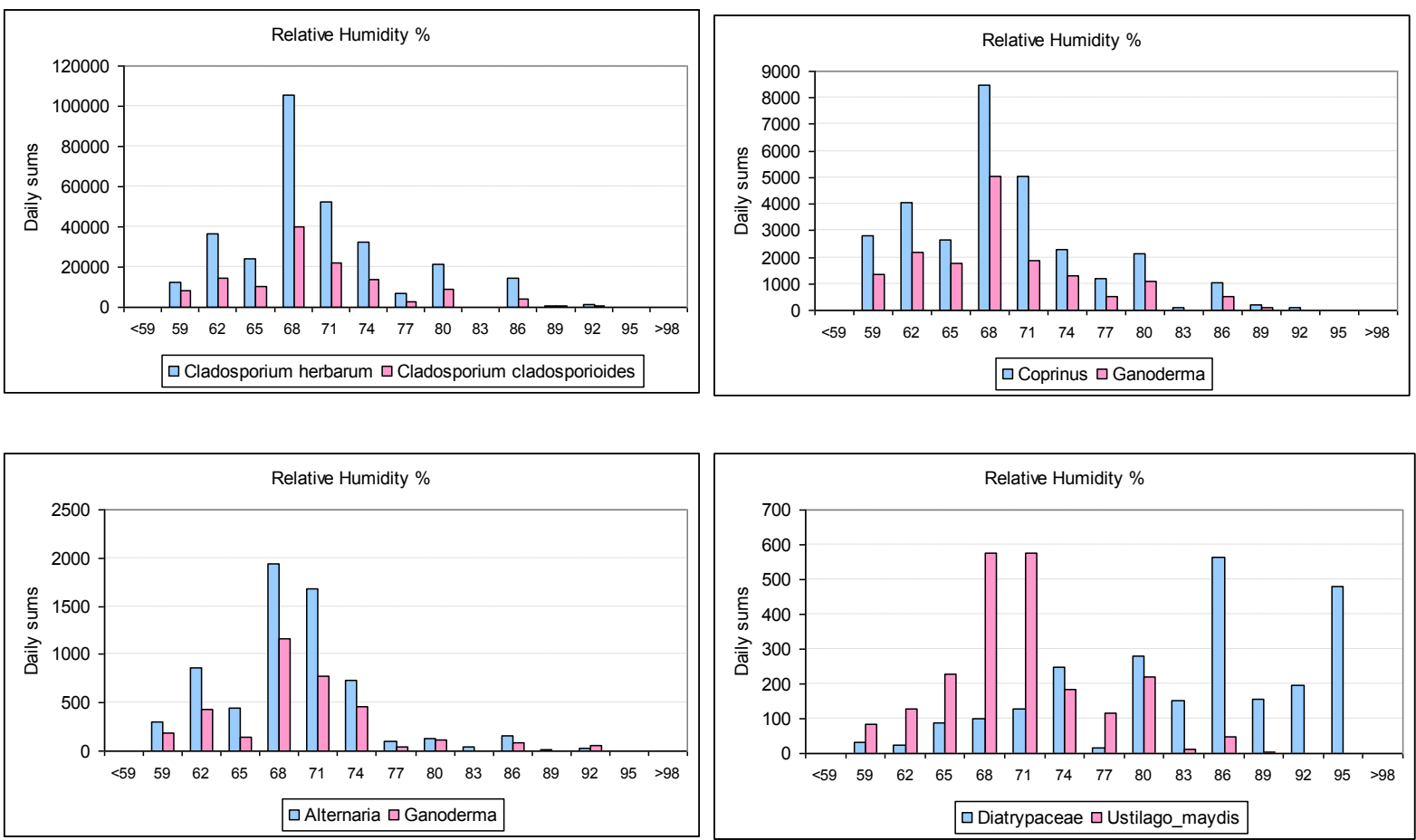

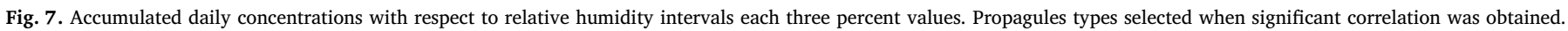

significance relationships. Graphical analyses of temperature and relative humidity were performed for the most abundant propagule types on the forty dates with the highest values. This choice was made in order to obtain the meteorological conditions associated with observing airborne spores. SPSS 15.0 software was used for the statistical analyses. Average values correspond to the whole period for any individual type studied.

\subsection{WIBS-4 technique}

The Wideband Integrated Bioaerosol Sensor (WIBS-4) created by Paul Kaye of the University of Hertfordshire is a single particle, on-line fluorescence spectrometer with the capability to determine the size, "shape" and fluorescence characteristics of ambient particles at a millisecond time resolution. It achieves this through the use of two xenon flash lamps set to excite at $280 \mathrm{~nm}$ and $370 \mathrm{~nm}$ respectively to gauge the fluorescent intensities of individual particles. It separately uses a $635 \mathrm{~nm}$ diode laser to establish their size and "shape" in terms of an asymmetry, AF, factor. The AF values are obtained by using the ratio of scattered light falling on a four quadrant detector; more detailed descriptions of this process have been discussed in great detail elsewhere (Gabey et al., 2010; Healy et al., 2012a).

Individual particle fluorescence is evaluated using three detector channels, termed FL1, FL2 and FL3. These channels record the total fluorescence over two wavelength ranges, namely, FL1 $=310-400 \mathrm{~nm}$ with both FL2 and FL3 $=420-650 \mathrm{~nm}$. Each particle is excited sequentially at $280 \mathrm{~nm}$ (FL1 and FL2) and then $370 \mathrm{~nm}$ (FL3). The WIBS-4 device used for the campaign discussed here is similar to those that have been described previously (Gabey et al., 2010; Healy et al., 2012a; Kaye et al., 2005). The WIBS-4 instrument does differ in important respects from its predecessor (WIBS-3) as noted in those reports (Healy et al., 2012a), especially as WIBS-4 allows the user to designate the size fraction of the ambient particles upon which to focus sampling and subsequent data analysis. This feature is related to two sensitivity settings in WIBS-4: High Gain (HG) and Low Gain (LG). HG allows particles between 0.5 and $10 \mu \mathrm{m}$ to be evaluated whilst LG allows particles from 1.2 to $22 \mu \mathrm{m}$ to be analysed. It should be noted that particles greater than $22 \mu \mathrm{m}$ will also be sampled but saturation of the sizing detector causes them to be labelled as particles with an optical diameter of $22 \mu \mathrm{m}$. The particle counting efficiency of the WIBS-4 has been previously studied by Healy et al. With the $D_{50} \sim 0.489 \mu \mathrm{m}$ and $D_{100} \sim 0.69 \mu \mathrm{m}$ defined for the instrument vs A TSI 3010 condensation particle counter (Healy et al., 2012b).

For the on-line measurements $v s$ the off-line method comparison only results from three-weeks between 1st and 20th July of the total campaign length were analysed because of the large data-sets that are collected using the real-time technique. The WIBS-4 was co-located with the Hirst trap on top of the MeteoSwiss research station and ran continuously. Its data were collected at milli-second resolution before being averaged into larger more manageable time bins (hourly or daily).

\section{Results}

The averaged meteorological data for the campaign period gave the following values: pressure $958.2 \mathrm{hPa}(940.0-969.0 \mathrm{hPa})$; relative humidity 74.9\% (59.8-95.3\%); wind speed $1.8 \mathrm{~m} / \mathrm{s}(0.7-5.0 \mathrm{~m} / \mathrm{s})$; wind direction mode $207^{\circ}$ (SSW); radiation $215 \mathrm{w} / \mathrm{m}^{2}\left(33-364 \mathrm{w} / \mathrm{m}^{2}\right)$; air temperature at $2 \mathrm{~m} 13.7{ }^{\circ} \mathrm{C}\left(-0.4-25.9^{\circ} \mathrm{C}\right)$; air temperature at $0.05 \mathrm{~m}$ $14.7{ }^{\circ} \mathrm{C}\left(-0.0-27.6{ }^{\circ} \mathrm{C}\right)$; total precipitation $431.4 \mathrm{~mm}$; sunshine duration $15.7 \mathrm{~min}(0-36.5 \mathrm{~min})$. A total of 134,105 propagules were counted over the whole period and $99.6 \%$ of them could be identified with 62 propagule types as shown in Table 1 . The propagules were distributed into 12 groups: conidia (23), ascospores (16), basidiospores (12), teliospores (4), urdedospores (1), aeciospores (1), oidia (1), sporangiospores (1), bryophyte spores (1), spores of Myxomycetes (1), and hyphae (1). The daily average concentration was 4145 propagules/ $\mathrm{m}^{3}$. Fig. 1 provides a representation of the twenty most frequently identified propagule types with an average concentration of at least 0.5 propagules $/ \mathrm{m}^{3}$. Four propagule types were found to represent $75 \%$ of the total captured: Cladosporium cladosporioides, Cladosporium herbarum, Coprinus and Venturia. The average concentration for conidia (2982 spores $/ \mathrm{m}^{3}$ ) was about $6 \times$ that of both ascospores $\left(544\right.$ spores $\left./ \mathrm{m}^{3}\right)$ and basidiospores (521 spores $/ \mathrm{m}^{3}$ ). The peak for total concentration was 
Results of correlation analysis for the 20 propagules types more abundant (p Spearman correlation coefficient, $r$ significance).

\begin{tabular}{|c|c|c|c|c|c|c|c|c|c|c|}
\hline & \multirow{2}{*}{$\frac{\text { Air Press. }}{\mathrm{r}}$} & \multirow[t]{2}{*}{$\mathrm{p}$} & \multirow{2}{*}{$\frac{\text { Rel. Hum. }}{\mathrm{r}}$} & \multirow[t]{2}{*}{$\mathrm{p}$} & Wind Sp. & $\mathrm{p}$ & Wind Dir. & \multirow[t]{2}{*}{$\mathrm{p}$} & \multirow{2}{*}{$\frac{\text { Radiation }}{\mathrm{r}}$} & \multirow[t]{2}{*}{$\mathrm{p}$} \\
\hline & & & & & $\mathrm{r}$ & & $\mathrm{r}$ & & & \\
\hline Abortiporus & 0.045 & 0.595 & -0.075 & 0.371 & 0.075 & 0.371 & 0.156 & 0.063 & 0.284 & 0.001 \\
\hline Agrocybe & 0.094 & 0.266 & -0.098 & 0.244 & -0.016 & 0.853 & 0.201 & 0.016 & 0.210 & 0.012 \\
\hline Alternaria & 0.330 & 0.000 & -0.349 & 0.000 & -0.231 & 0.006 & -0.003 & 0.975 & 0.426 & 0.000 \\
\hline Amanita & 0.366 & 0.000 & -0.087 & 0.303 & -0.272 & 0.001 & 0.091 & 0.281 & 0.297 & 0.000 \\
\hline Aspergillus-Penicillium & -0.173 & 0.039 & 0.102 & 0.228 & -0.065 & 0.438 & -0.007 & 0.938 & -0.232 & 0.005 \\
\hline Basidiospores & 0.128 & 0.128 & -0.076 & 0.367 & -0.132 & 0.117 & 0.138 & 0.102 & 0.270 & 0.001 \\
\hline Botrytis & 0.313 & 0.000 & -0.150 & 0.073 & -0.061 & 0.467 & 0.097 & 0.252 & 0.413 & 0.000 \\
\hline Cladosporium_cladosporioides & 0.501 & 0.000 & -0.421 & 0.000 & -0.237 & 0.004 & -0.038 & 0.652 & 0.567 & 0.000 \\
\hline Cladosporium_herbarum & 0.533 & 0.000 & -0.399 & 0.000 & -0.283 & 0.001 & -0.049 & 0.565 & 0.606 & 0.000 \\
\hline Coprinus & 0.597 & 0.000 & -0.445 & 0.000 & -0.307 & 0.000 & -0.011 & 0.898 & 0.627 & 0.000 \\
\hline Diatrypaceae & -0.176 & 0.035 & 0.342 & 0.000 & -0.089 & 0.288 & 0.181 & 0.031 & -0.258 & 0.002 \\
\hline Didymella & 0.081 & 0.336 & -0.002 & 0.980 & -0.022 & 0.796 & 0.030 & 0.726 & 0.242 & 0.004 \\
\hline Epicoccum & 0.396 & 0.000 & -0.331 & 0.000 & -0.255 & 0.002 & -0.055 & 0.514 & 0.455 & 0.000 \\
\hline Ganoderma & 0.410 & 0.000 & -0.408 & 0.000 & -0.204 & 0.014 & -0.011 & 0.893 & 0.611 & 0.000 \\
\hline Hyphae & 0.306 & 0.000 & -0.480 & 0.000 & -0.173 & 0.039 & -0.091 & 0.282 & 0.524 & 0.000 \\
\hline Leptosphaeria & 0.265 & 0.001 & 0.079 & 0.346 & -0.040 & 0.639 & 0.231 & 0.006 & 0.232 & 0.005 \\
\hline Leptosphaeria_(hyaline) & 0.396 & 0.000 & -0.149 & 0.076 & -0.134 & 0.110 & 0.127 & 0.132 & 0.427 & 0.000 \\
\hline Ustilago_maydis & 0.252 & 0.002 & -0.239 & 0.004 & 0.074 & 0.383 & -0.016 & 0.850 & 0.329 & 0.000 \\
\hline Venturia & 0.229 & 0.006 & 0.049 & 0.561 & -0.080 & 0.340 & 0.218 & 0.009 & 0.181 & 0.030 \\
\hline \multirow[t]{3}{*}{ Venturia_(hyaline) } & 0.184 & 0.028 & 0.152 & 0.070 & -0.131 & 0.120 & 0.226 & 0.007 & 0.115 & 0.172 \\
\hline & \multicolumn{2}{|c|}{ Air Temp $2 \mathrm{~m}$} & $\mathrm{p}$ & Air Temp $5 \mathrm{~cm}$ & $\mathrm{p}$ & \multicolumn{2}{|r|}{ Rain } & $\mathrm{p}$ & Sunshine & $\mathrm{p}$ \\
\hline & \multicolumn{2}{|l|}{$\mathrm{r}$} & & \multicolumn{2}{|l|}{$\mathrm{r}$} & \multicolumn{2}{|r|}{$\mathrm{r}$} & & \multicolumn{2}{|l|}{$\mathrm{r}$} \\
\hline Abortiporus & \multicolumn{2}{|l|}{0.333} & 0.000 & 0.345 & 0.000 & & -0.020 & 0.814 & 0.167 & 0.046 \\
\hline Agrocybe & 0.171 & & 0.042 & 0.198 & 0.018 & & -0.032 & 0.704 & 0.123 & 0.143 \\
\hline Alternaria & 0.686 & & 0.000 & 0.679 & 0.000 & & -0.281 & 0.001 & 0.461 & 0.000 \\
\hline Amanita & 0.590 & & 0.000 & 0.580 & 0.000 & & -0.158 & 0.059 & 0.223 & 0.007 \\
\hline Aspergillus-Penicillium & -0.318 & & 0.000 & -0.305 & 0.000 & & 0.077 & 0.362 & -0.227 & 0.006 \\
\hline Basidiospores & 0.342 & & 0.000 & 0.356 & 0.000 & & -0.074 & 0.379 & 0.183 & 0.028 \\
\hline Botrytis & 0.600 & & 0.000 & 0.600 & 0.000 & & -0.099 & 0.239 & 0.321 & 0.000 \\
\hline Cladosporium_cladosporioides & 0.841 & & 0.000 & 0.833 & 0.000 & & -0.315 & 0.000 & 0.543 & 0.000 \\
\hline Cladosporium_herbarum & 0.848 & & 0.000 & 0.846 & 0.000 & & -0.393 & 0.000 & 0.557 & 0.000 \\
\hline Coprinus & 0.826 & & 0.000 & 0.826 & 0.000 & & -0.403 & 0.000 & 0.555 & 0.000 \\
\hline Diatrypaceae & -0.018 & & 0.827 & -0.044 & 0.603 & & 0.426 & 0.000 & -0.246 & 0.003 \\
\hline Didymella & 0.315 & & 0.000 & 0.315 & 0.000 & & -0.041 & 0.631 & 0.142 & 0.092 \\
\hline Epicoccum & 0.750 & & 0.000 & 0.739 & 0.000 & & -0.289 & 0.000 & 0.464 & 0.000 \\
\hline Ganoderma & 0.814 & & 0.000 & 0.809 & 0.000 & & -0.313 & 0.000 & 0.533 & 0.000 \\
\hline Hyphae & 0.687 & & 0.000 & 0.683 & 0.000 & & -0.331 & 0.000 & 0.519 & 0.000 \\
\hline Leptosphaeria & 0.475 & & 0.000 & 0.478 & 0.000 & & 0.082 & 0.331 & 0.131 & 0.119 \\
\hline Leptosphaeria_(hyaline) & 0.614 & & 0.000 & 0.618 & 0.000 & & -0.148 & 0.078 & 0.326 & 0.000 \\
\hline Ustilago_maydis & 0.318 & & 0.000 & 0.319 & 0.000 & & -0.141 & 0.092 & 0.234 & 0.653 \\
\hline Venturia & 0.452 & & 0.000 & 0.448 & 0.000 & & 0.082 & 0.332 & 0.096 & 0.005 \\
\hline Venturia_(hyaline) & 0.343 & & 0.000 & 0.349 & 0.000 & & 0.172 & 0.040 & 0.038 & 0.254 \\
\hline
\end{tabular}

reached on July 19th, with 26,109 propagules $/ \mathrm{m}^{3}$. Cladosporium herbarum and Cladosporium cladosporioides were found to be the propagule types found in the greatest abundance. They were most prevalent in July and August where maximum number concentrations were monitored on $30^{\text {th }}$ July and 6th August respectively, as shown in Fig. 2.

Correlation with the meterological parameters showed statistically significant positive trends with temperature, sunshine, air pressure and radiation. Negative correlations were observed with relative humidity, rain and wind speed. Cladosporium herbarum was most abundant at $20{ }^{\circ} \mathrm{C}$ whereas for Cladosporium cladosporioides it was $20-24{ }^{\circ} \mathrm{C}$. These results are summarized in Fig. 2. The most abundant ascospores were Venturia, Leptosphaeria, Didymella and Diatrypaceae including separate hyaline forms for the first two types. Both Venturia and Leptosphaeria showed their highest concentrations during July with correlations apparent for all hyaline forms. It was also noted that the number concentrations for Venturia and Leptosphaeria types were reached on the same day, July 19th. In contrast for Didymella the peak was reached on May 10th and for Dyatripaceae on March $30^{\text {th }}$. Temperature was positively correlated with the first three types of ascospore but not for Dyatripaceae as shown in Fig. 3.

The basidiospores collected were, in order of abundance: Coprinus,
Ganoderma, Agrocybe, Abortiporus, Amanita and then "others". Peaks of concentration were reached in July for Coprinus (9th), Ganoderma (19th) and Amanita (19th), in May for Agrocybe (7th), Abortyporus (16th) and for other basidiospores (8th). Temperature was positively correlated with basidiospores except for the Agrocybe type. Rain and relative humidity were negatively correlated to Coprinus and Ganoderma. These results are summarized in Fig. 4. Other abundant conidia that were identified included Aspergillus-Penicillium, Alternaria, Botrytis and Epiccocum. The Aspergillus-Penicillium type reached maximum concentrations on April 25th, whereas the others maximised later in the year with Alternaria on August 7th, Botrytis on June 13th and Epicoccum on August 6th. Again in contrast Aspergillus-Penicillium showed a negative correlation with temperature, while the other three types were positively correlated as shown in Fig. 2. Hyphae showed their peak of concentration on August 1st and positive correlations with temperature were found. Ustilago maydis reached its peak of concentration on June 13th and also showed a positive correlation with temperature as shown in Fig. 5. In relation to the full meteorological data set, the parameter that showed the greatest number of correlations was temperature, with only Agrocybe and Diatrypacea not showing any significant correlations. These correlations were always positive except 

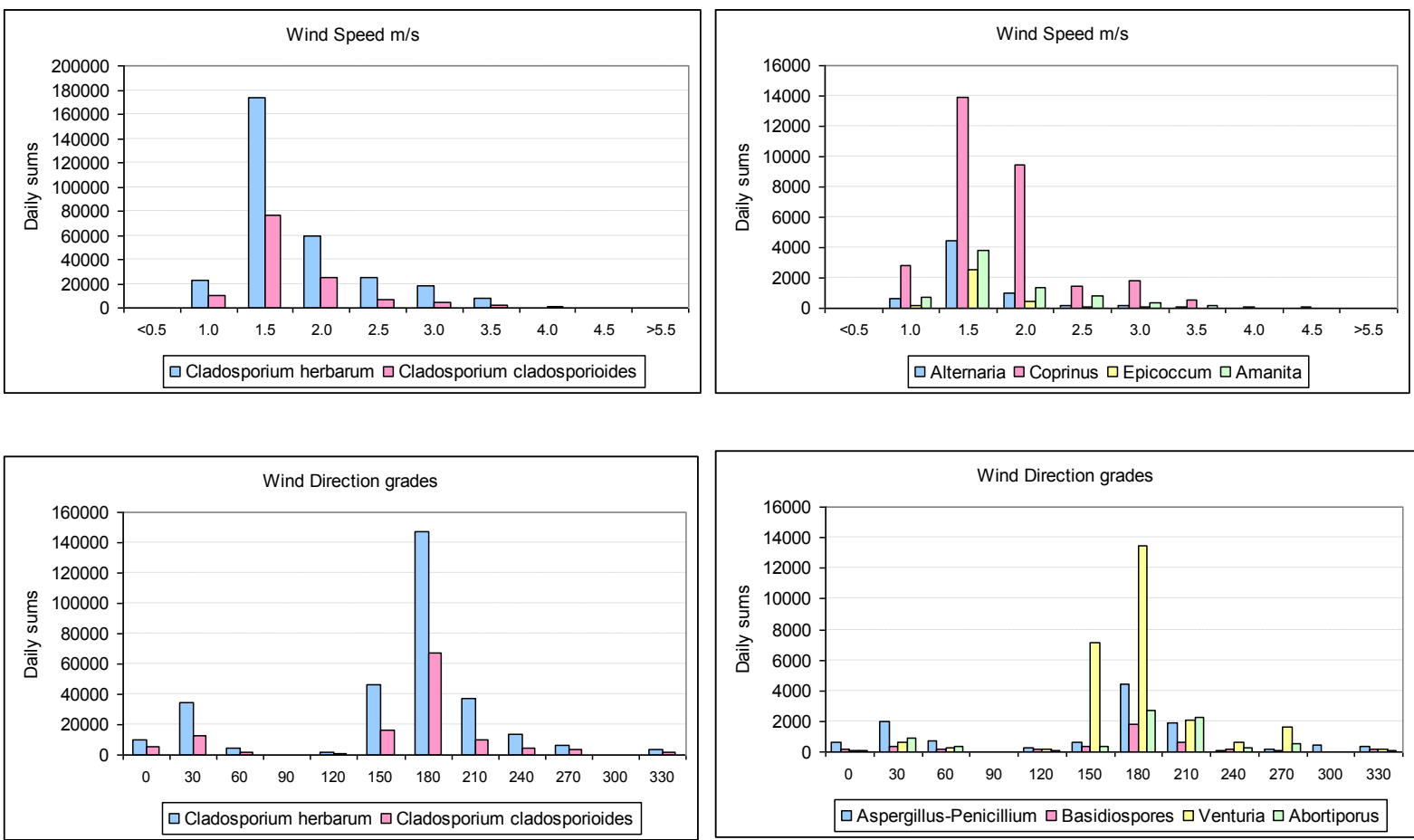

Fig. 8. Accumulated daily concentrations with respect to wind speed and directions. Propagules types selected when significant correlation was obtained.

for the Aspergillus-Penicillium type. The optimum temperature for release of most propagules varied between the different types. The range was $18-20{ }^{\circ} \mathrm{C}$ for seven of the propagule types: Cladosporium herbarum, Cladosporium cladosporioides, Botrytis, Venturia, Leptosphaeria, Coprinus, Ganoderma. It seems for spore release that some types require warmer conditions with favorable temperatures of $20-22{ }^{\circ} \mathrm{C}$ (Amanita) and 22-24 ${ }^{\circ} \mathrm{C}$ (Alternaria, Hyphae, Epicoccum, Ustilago maydis). Propagule types that were associated with colder temperatures for release were: Aspergillus-Penicillium at $14-16{ }^{\circ} \mathrm{C}$; basidiospores and Didymella at $12-14{ }^{\circ} \mathrm{C}$; Agrocybe, and Abortiporus at $10-12{ }^{\circ} \mathrm{C}$; Diatrypaceae at $2-4{ }^{\circ} \mathrm{C}$ as shown in Fig. 6. Relative humidity values showed statistically significant negative correlation for release in all cases except one. Hence it was significant in all propagule types, except for Diatrypaceae, which showed significant positive correlation. Highest spore concentration were measured at relative humidity between 68 and 71\%, except for Diatrypaceae with $86 \% \mathrm{RH}$ as shown in Fig. 7. Increased wind speed never impacted positively on number concentrations and in six types there were statistically significant negative correlations as shown in Table 2. For all cases, values between 1 and $1.5 \mathrm{~m} / \mathrm{s}$ represented the best wind speed to effect collection of airborne propagules. In relation to wind direction the highest concentrations were reached when winds blew from SSW. The results are summarized in Fig. 8. Graphical analyses comparing temperature and relative humidity are shown in Fig. 9 and are discussed below. The range of other meteorological conditions noted with the 5 most abundant types were for Cladosporium herbarum, $13-26{ }^{\circ} \mathrm{C}(59-88 \% \mathrm{RH})$, Cladosporium cladosporioides, $12-26{ }^{\circ} \mathrm{C}(59-88 \%$ $\mathrm{RH})$, Coprinus, $13-26{ }^{\circ} \mathrm{C}(59-81 \% \mathrm{RH})$, Leptosphaeria, 7-24 ${ }^{\circ} \mathrm{C}(63-91 \%$ $\mathrm{RH})$, Venturia, $6-26{ }^{\circ} \mathrm{C}(59-91 \% \mathrm{RH})$, Ganoderma, $17-26{ }^{\circ} \mathrm{C}(59-89 \%$ $\mathrm{RH})$.

Fig. 10 shows the results of the comparison between the on-line and off-line methods utilized during the campaign. As can be seen in Fig. 10 (A) a clear correlation $\left(\mathrm{R}^{2}=0.81, \mathrm{p}<0.001\right)$ between the two instruments for daily concentrations is apparent. This relationship is particularly evident at the end of the three-week campaign where both instruments show a dominant peak. On average the WIBS-4 instrument was seen to display higher daily concentrations than the Hirst-type impactor/optical microscopy combination. In fact, the WIBS-4 reported number-concentrations approximately twice provided by impaction. However it should be re-iterated that the techniques are based on quite different principles. Hence the traditional approach is operator dependent as the PBAP are counted by eye with a lower size limit $\sim 2 \mu \mathrm{m}$ and only a portion of the sample is actually analysed. In contrast the WIBS-4 directly counts all of the fluorescent particles that have sizes $>2 \mu \mathrm{m}$. This correlation between the instruments was seen to drop significantly $\left(\mathrm{R}^{2} \sim 0.2\right)$ once the time resolution (3 hourly) for the readings was increased. It should be noted that the WIBS-4 will also count all fluorescent particles in the detection range which could encompass particles such as bacteria which can have physical diameter between 0.5 and 5 microns. It was noted however that good correlations between the two techniques could be attained at higher resolution if the contributions of Cladosporium spp were removed from the total fungal spore counts. For this treatment, as shown in Fig. 10 (B), where a $\mathrm{R}^{2}$ value above 0.6 was calculated. It is of note that dilution was taken account of throughout the study.

\section{Discussion}

There is no uniform method for studying airborne fungal propagules because of the inherent difficulties in counting and identifying by eye the numerous and diverse species that can be present in the atmosphere. Therefore, by using light microscopy (LM) with magnifications × 400 (Grinn-Gofroń, 2011; O'Connor et al., 2014; Oliveira et al., 2009) or $\times 650$ (Nikkels et al., 1996) it is not possible, or at least challenging, to identify, distinguish and count properly the smallest spores $(<2 \mu \mathrm{m})$ or morphologically similar spores such as Aspergillus-Penicillium. Hyaline spores are also very difficult to count and assess. We consider the slide area measured and number of propagules counted to comprise the statistical sampling size necessary to produce reliable information (Tormo-Molina et al., 1996, 2013). Hence, it is problematic to put much of the spore counting and identification work currently published into any systematic comparison study because in many cases no indication of magnification is available in the cited reports (Ballero et al., 1992; Herrero et al., 2006; Kasprzyk and Worek, 2006). Moreover, counting methods often use different approaches e.g. two full lengthwise 


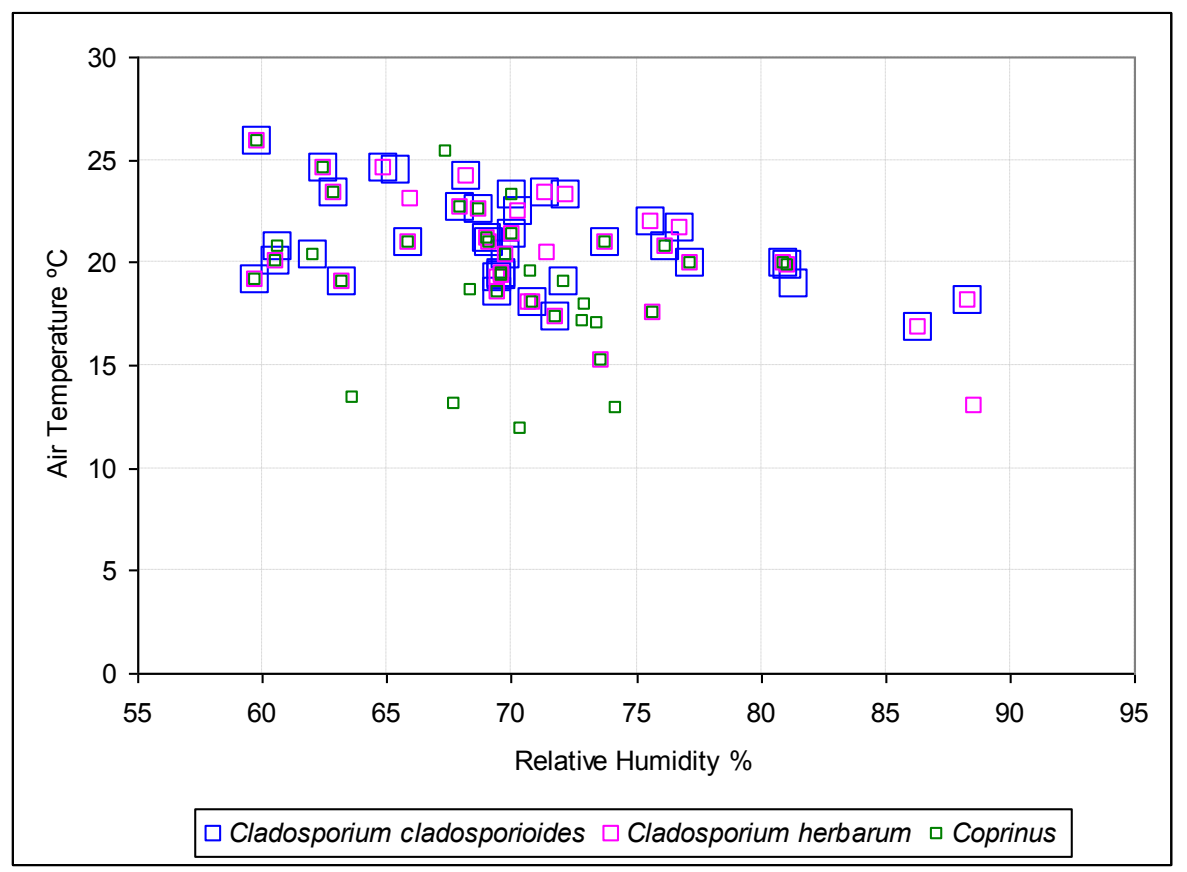

Fig. 9. Relation between air temperature and relative humidity including the 40 days with the higher values of concentration for the five more abundant propagules types.

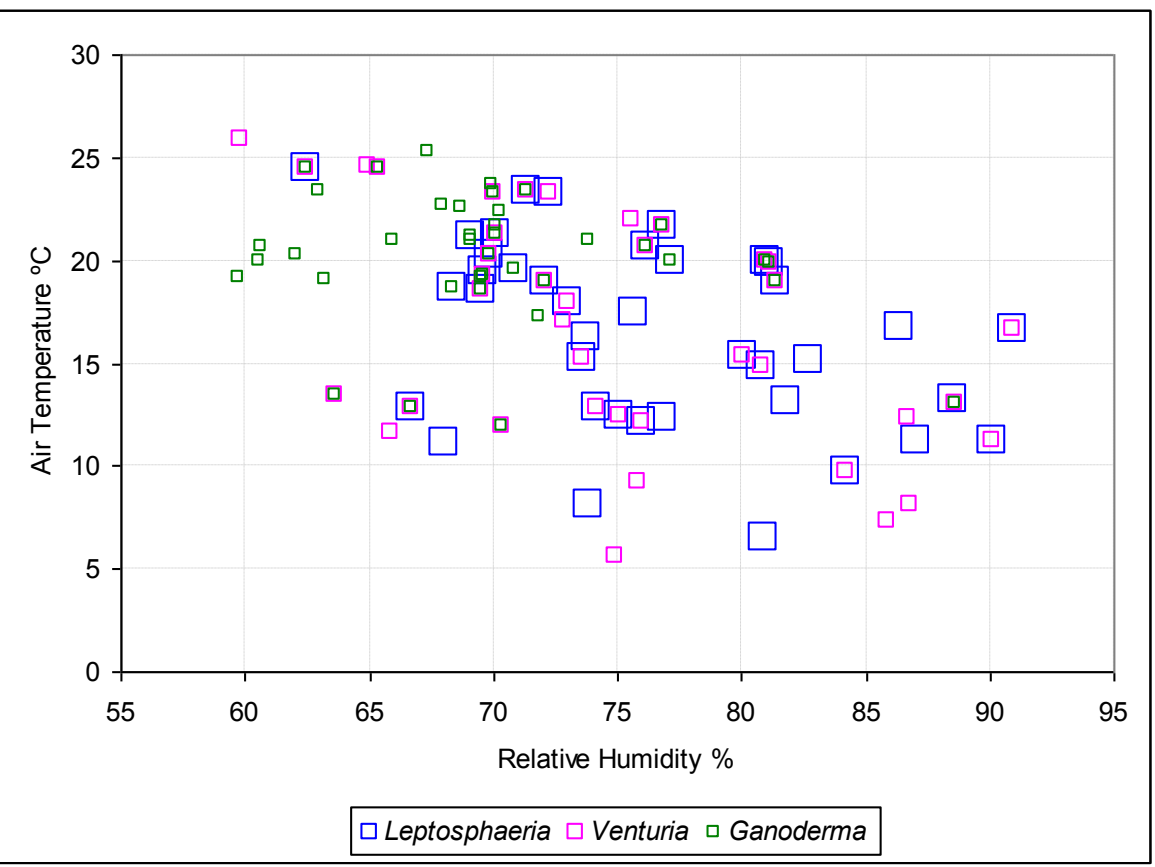

traverses (Oliveira et al., 2009) or one horizontal transect (GrinnGofroń, 2011; Kasprzyk and Worek, 2006; Nikkels et al., 1996) or along 12 horizontal transects (O'Connor et al., 2014). However most monitoring campaigns do employ a Hirst-type (impaction) spore trap, although one case where a personal spore trap was used has been published (Pyrri and Kapsanaki-Gotsi, 2007).

In the current study, in order to count and identify as many spore types as possible, a $\times 1000 \mathrm{LM}$ magnification was used, as average absolute counts per slide were more than 900 spores. Only one longitudinal scan was necessary because the number of scans depended mainly on the total number of airborne particles present (Tormo-Molina et al., 1996, 2013). It is also of note that the surface of the sampled slide is representative (Comtois et al., 1999; Galán et al., 2014). In addition, as mentioned above, hyaline propagules are difficult to count, in this study five types were fully characterized: Amanita (basidiospores more than $10 \mu \mathrm{m}$ length), Abortiporus (basidiospores about 5-9 $\mu \mathrm{m}$ length), Leptosphaeria, Ventura, Didymella (bicellular ascospores more than $10 \mu \mathrm{m}$ length). However, many of the hyaline spore contributions were identified with very small spores, often $<5 \mu \mathrm{m}$. It was found that Cladosporium cladosporioides, Aspergillus-Penicillium, Lycoperdon, Paraphaeosphaeria, Venturia represented more than $30 \%$ of total airborne spores.

In total sixty-three propagule types were collected but there are few studies to compare this number with. Indeed, many of the published reports were focused on grouping spores together in order to reduce the number of fungal types. Nonetheless, the Payerne figures (and mean concentrations of propagules measured) are considerably higher than found in most other studies performed throughout Europe: 50 in Portugal (Oliveira et al., 2009), 26 in Greece (Pyrri and KapsanakiGotsi, 2007), 26 in Spain (Muñoz-Rodríguez et al., 1996), 19 in Italy 

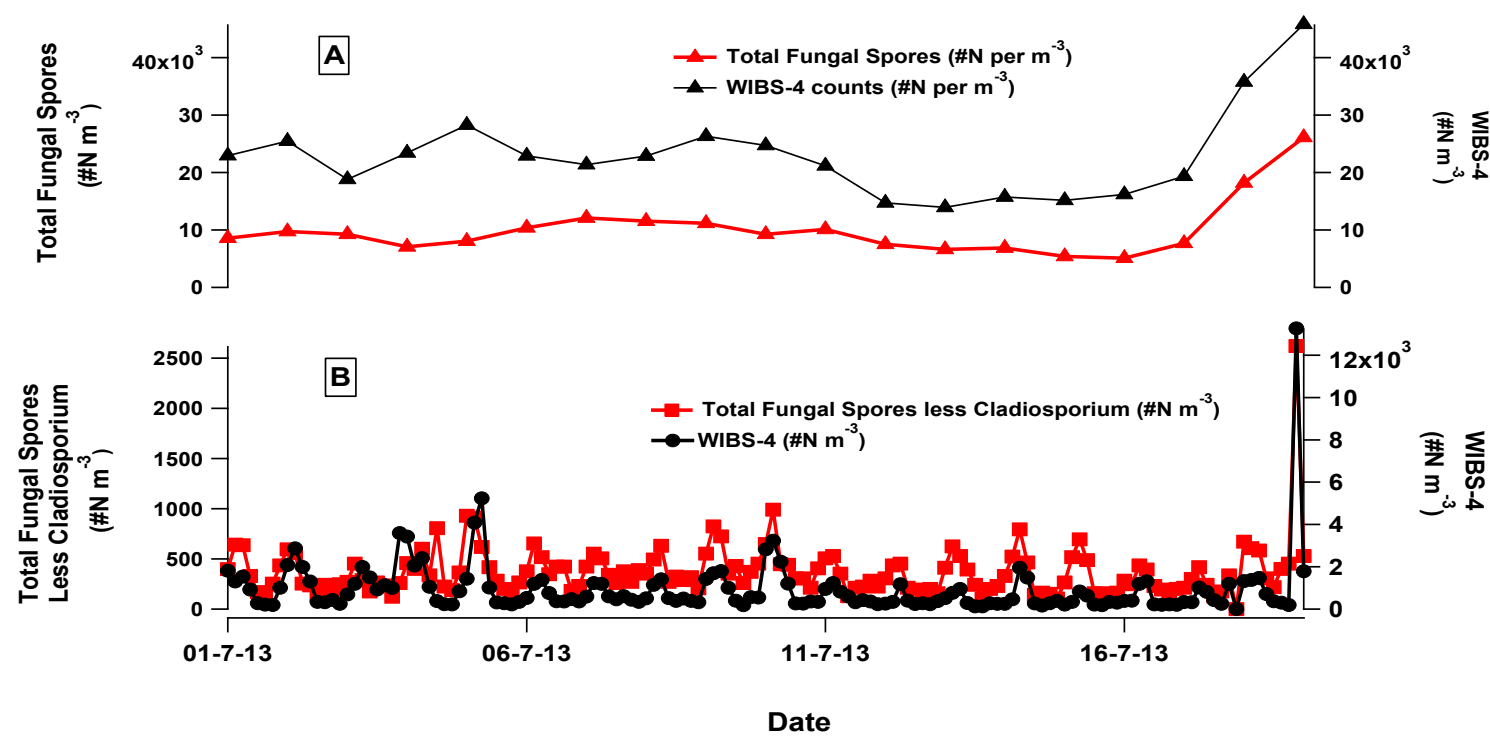

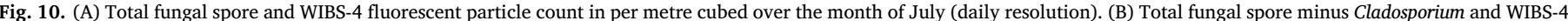
fluorescent particle count in per metre cubed over the month of July ( $3 \mathrm{~h}$ resolution).

(Ballero et al., 1992). In fact just one case does report greater numbers than given here: 70 in Madrid (Herrero et al., 2006). The peak concentrations of total propagules measured here were higher than those found in Portugal (Oliveira et al., 2009) and Greece (Pyrri and Kapsanaki-Gotsi, 2007). The most abundant propagule types were similar to those found in other comparable studies in Europe outlined above (Herrero et al., 2006; Muñoz-Rodríguez et al., 1996; Oliveira et al., 2009). Hence Cladosporium is always the most abundant spore monitored and always with a greater than $50 \%$ contribution to the loading.

In Payerne, the Cladosporium average concentrations obtained were higher than those measured in Portugal (Oliveira et al., 2009), Ireland (O'Connor et al., 2014), Greece (Pyrri and Kapsanaki-Gotsi, 2007) and Italy (Ballero et al., 1992). However similar values have been found in Poland (Grinn-Gofron et al., 2015; Kasprzyk and Worek, 2006) and the Netherlands (Nikkels et al., 1996). It is lower than those reported in a study performed in UK (O'Connor et al., 2014). Positive correlations with temperature were also found in Portugal (Oliveira et al., 2009), Ireland and UK (O'Connor et al., 2014), and Italy (Ballero et al., 1992). It is also worth reporting that in the current study separation between Cladosporium cladosporioides and Cladosporium herbarum was obtained unlike any other prior European study.

For Alternaria the average concentration obtained in this study was higher than those measured in Portugal (Oliveira et al., 2009), Ireland and UK (O'Connor et al., 2014) but is similar to the results found in Greece (Pyrri and Kapsanaki-Gotsi, 2007), Poland (Grinn-Gofroń et al., 2016; Kasprzyk and Worek, 2006), the Netherlands (Nikkels et al., 1996) and Italy (Ballero et al., 1992). In agreement with other reports a positive correlation with temperature was observed, although it is worth commenting on the fact that the collection made in Portugal (Oliveira et al., 2009) indicated a negative correlation with temperature.

For Aspergillus-Penicillium, concentrations obtained in this study were higher than found in Portugal (Oliveira et al., 2009), Poland (Grinn-Gofroń, 2011) and Spain (Herrero et al., 2006). A negative correlation with temperature was also observed in Portugal (Oliveira et al., 2009) and positive with relative humidity in Poland (GrinnGofroń, 2011). For Ganoderma, concentrations obtained in this study were higher than found in Ireland and UK (O'Connor et al., 2014) but were similar to those values determined in Poland (Kasprzyk and Worek, 2006). Positive correlations with temperature were also found in Ireland and UK (O'Connor et al., 2014). For Didymella, concentrations obtained in this study were lower than reported in Ireland and UK (O'Connor et al., 2014). Positive correlation with temperature also was determined in Ireland (O'Connor et al., 2014). For Drechslera, the concentrations were measured to be higher than those found in Poland (Kasprzyk and Worek, 2006) but were similar to the levels in Italy (Ballero et al., 1992).

For Coprinus, the concentrations obtained were higher than measured in Spain (Herrero et al., 2006). For Ustilago, concentrations were found to be lower than in Spain (Herrero et al., 2006) and the Netherlands (Nikkels et al., 1996). For Botrytis, the concentrations found in our study were lower than seen in The Netherlands (Nikkels et al., 1996). For Epicoccum, the concentration was higher to that measured in The Netherlands (Nikkels et al., 1996). However, it is necessary to emphasize that those studies were not performed on the same periods and variation between years may be significant.

Hyphal fragments have rarely been taken into account with any of the previous studies but from the results determined in Payerne the concentrations were higher than measured in Greece (Pyrri and Kapsanaki-Gotsi, 2007). The proportions of ascospores and basidiospores were found to be similar in our study, which is in complete contrast to the study made in Spain (Herrero et al., 2006) where basidiospores represented twice the contribution that the ascospores made.

The negative effect of wind speed on fungal propagule concentrations has also been observed previously, without discarding the dilution effects (Grinn-Gofron et al., 2016). Graphical analysis of weather parameters showed that a temperature of $20{ }^{\circ} \mathrm{C}$ often represents the point to obtain maximum propagule concentrations and that higher temperatures may maintain this concentration or even decrease it (Cladosporium herbarum, Cladosporium cladosporioides, Botrytis, Lepthosphaeria, Venturia, Coprinus, Ganoderma). There are some cases for which higher temperatures appear to be required (Alternaria, Amanita) and some for which lower temperatures represent an optimal condition (Aspergillus-Penicillium, Abortiporus, Diatrypaceae, Dydimella, basidiospores), both because the highest values appeared when temperature reached $22-24{ }^{\circ} \mathrm{C}$ and $10-16{ }^{\circ} \mathrm{C}$ respectively. These results are summarized in Fig. 6 . With respect to relative humidity, $68 \%$ appears to represent a threshold to promote higher airborne propagule concentrations of virtually all types studied. However, Diatrypaceae require higher values: above $\sim 86 \%$. Different values have been found in literature with respect to the optimum in relative humidity, most of them for Alternaria and Cladosporium: 50-60\% (Herrero et al., 1996), 80\% (Rodriguez-Rajo et al., 2005), 60\% (Maya-Manzano et al., 2012). The 
highest values of propagule concentrations in the air are always found at wind speeds of $1.5 \mathrm{~m} / \mathrm{s}$. Higher spores concentrations are found when the winds blow from SW, which is the prevailing wind direction and the direction of mixed Coniferous forests, which is likely to be an important source contributor, as inspection of satellite images shows that agricultural activities result in a nearly homogenous distribution in all directions. The relationship between temperature and relative humidity for controlling the presence of airborne fungal propagules has been widely discussed in the scientific literature. From Fig. 9 it proves possible to distinguish, in relation to temperature tolerance, between fungal propagules requiring a narrow range of the parameter (i.e both types of Cladosporium) and those able to be present over a wide range (i.e. Leptosphaeria, Venturia, Ganoderma). In relation to relative humidity, the range of tolerance seems to be wide in all fungal propagule types collected.

\subsection{Fungal concentrations: WIBS-4 vs Hirst-type/optical microscopy}

It has been suggested previously that by filtering both the FL1 and FL3 channel data for WIBS, potential false positives caused by mineral dust can be minimised (Toprak and Schnaiter, 2012). Hernandez et al. (2016) evaluated a number of fungal spores, bacteria and pollen grains with most seen to predominately fluorescence in the FL1 channel alone (termed A type particles), however almost all types were partially seen to fluoresce in all three channels (termed ABC particles) (Hernandez et al., 2016). It has also been established in previous studies that signals measured in the FL3 channel are likely important for detecting fungal spores (Gabey et al., 2010, 2011, 2013). Thus in the current study a filter utilising all channel thresholds (ie 3 times the standard deviation plus mean fluorescence signal of the WIBS whilst in forced trigger mode.) and a size component ( $>2 \mu \mathrm{m}$ ) was applied to the WIBS data. This gave good correlations, as can be seen above in Fig. 10(A) and (B) albeit at differing time resolutions. Such particles have been termed $A B C$ type particles throughout the literature (Perring, 2015). The thresholds used in the filtering of these data was attained by placing the WIBS- 4 instrument into Forced Trigger (FT) mode each day as to ensure that a reliable baseline threshold was calculated throughout the monitoring campaign. Thus prior to sampling the WIBS was run in FT mode for approximately $5 \mathrm{~min}$ each day. FL1,2 and 3 values were seen to vary between $4 \pm 1,17 \pm 2,15 \pm 4$ respectively over the course of the campaign. The data for WIBS between 1.2 and $2 \mu \mathrm{m}$ has no counterpart with the optical microscopy technique and was hence removed during the data processing (size filter mentioned above). This size filter negligibly affected the reported $\mathrm{R}^{2}$ values however (only slightly increasing it). This is most likely due to the fact that while the size filter should most likely remove bacteria (as they predominantly exist in this size range) few if any have $\mathrm{ABC}$ particle fluorescence characteristics (Hernandez et al., 2016) and thus would have already been removed via the fluorescence filter indicated. At high time resolutions the correlations were less good during this period $\left(\mathrm{R}^{2} \sim 0.2\right)$ and may be due to a number of the reasons as discussed below. The WIBS instrument appears to not respond to large increases in Cladosporium. Indeed this is not the first time that a field monitoring campaign using a WIBS-4 has seen the apparent disconnect between monitored florescent particles and large peaks in Cladosporium counts (via microscopy). In that earlier study, significant Cladosporium peaks were not counted by WIBS-4 (Healy et al., 2014; O'Connor et al., 2015). A number of reasons for this discrepancy were suggested, from the physical coordination of Cladosporium upon release, as it tends to be released in large clumps and clusters to potentially its photo-chemical make-up. It should be noted that during laboratory testing that Cladosporium has been seen to exhibit fluorescence (Healy et al., 2012b; Hernandez et al., 2016). Thus the physical coordination explanation for such particles is the most likely. Similarly given the orientation of the inlet during this work larger particles would experience increased wall loss. Thus removal of Cladosporium from the total fungal count was applied in the current study and upon doing so a much increased correlation was seen at higher time resolutions. This effect can be seen in Fig. 10 (B) which shows three-hourly data for fungal spores concentrations with Cladosporium removed. A substantially increased $\mathrm{R}^{2}$ value of $\sim 0.6 \mathrm{p}<0.001$ was found by doing so. Of course there are other potential reasons for the lack of co-linearity initially between the two instruments at higher resolutions. Hence while the Burkard/Hirst can be used to discriminate fungal spores from other ambient particles the WIBS-4 could be influenced by a number of potential interferences both biological and chemical, especially at smaller size ranges.

Given the nature of the WIBS- 4 instrument ambient bacteria will also cause a fluorescent signal in WIBS instrument, particularly in the FL1 and FL2 channels. Thus the larger ambient concentrations in both channels could indicate the presence of such particles. While the size range used in this sampling would preclude the majority of liberated bacterial cells $0.5-2 \mu \mathrm{m}$, agglomerates and even bacterial particles adhered to other ambient aerosols could be lead to anomalies. Due to the general ambient concentrations of bacteria which can be as high as $10^{-5}-10^{-6} \mathrm{~m}^{-3}$, they could significantly modify FAP counts (Bowers et al., 2011; Després et al., 2012). Atmospherically degraded pollen (sub-pollen units) could also contribute to differences observed using the two methods. Studies have found that pollen has the potential to rupture into fine sized particles, approximately $3 \mu \mathrm{m}$ in size (Schappi et al., 1997; Suphioglu et al., 1992). Hence single pollen could have the potential to generate a number of smaller particles which would not be registered by Burkard/Hirst traps. Several components of pollen are known to fluoresce and also could cause positive signals in the WIBS (Pöhlker et al., 2012, 2013). Anthropogenic and other non-biological particles may also contribute to the FAP count which in turn would affect the correlation seen above.

Finally physical aspects of the WIBS sampling inlet were not ideal. The inlet was $\sim 1.5 \mathrm{~m}$ in length, and bent to a $90^{\circ}$ angle thus losses such as inertial deposition due to the bend in the inlet were increased (vertical inlets minimize such wall loss) this significantly added to the impactation, sedimentation and diffusion losses (Inlet efficiency drops to $50 \%$ particles $>12 \mu \mathrm{m}$ ). The inlet was fitted to a weather vain. This set-up was used as to ensure that no rain water would be sampled and to allow the sampling head to face directly into the wind.

\section{Conclusions}

In spite of the fact that a longer sampling study, including a winter period, is required to obtain a complete survey of the fungal propagules in the air and to assess year to year variability, the results from this work provide a first view of airborne fungal propagules present in Switzerland by use of a volumetric spore trap and a real-time fluorescence instrument capable of detecting individual biological particles. Comparison with other European areas monitored using similar approaches indicate that airborne fungal propagule concentrations are noticeably higher in Payerne. Different factors may be put forward to explain this finding because of the range of site locations studied in different regions and micro-climates. It is also notable that in contrast to the prior studies this one used optical microscopy employing $\times 1000$ magnification. Hence other studies will likely underestimate the real number of fungal propagules because many of them have a size $<5 \mu \mathrm{m}$ and the fact that hyaline propagules are easily missed. Weather parameters showed a statistically significant association with observed spore concentrations. Temperature and relative humidity are especially important and are oppositely correlated; most types reach their highest concentrations with temperatures above $20{ }^{\circ} \mathrm{C}$, although there are a very few exceptions. $68 \%$ relative humidity appears to be the most suitable value to reach the higher fungal propagule concentrations in the air. Coniferous forest may be a relevant source for airborne fungal propagules as their distribution and predominant wind directions could show the origin (Mensah-Attipoe et al., 2016; Norros et al., 2012). Clearly more studies of the type reported here should become routinely 
performed in order to make quality assured comparisons of airborne spore numbers and identities in different localities. Few comparisons between on-line and off-line approaches to monitoring PBAP are found in the literature. The work presented here shows that at least for spores $>2 \mu \mathrm{m}$ in size, it is possible to obtain correlation between the techniques, taking into account the anomalous behaviour of Cladosporium.

\section{Acknowledgements}

This work was conducted thanks to the Regional Government of the Junta de Extremadura in Spain (Project Number PRI06A190) and the European Social Fund (Project number PRI BS10008, Research Group Fund GR15060).

\section{References}

Aira, M.J., Rodríguez-Rajo, F.J., Fernández-González, M., Seijo, C., Elvira-Rendueles, B., Abreu, I., Gutiérrez-Bustillo, M., Pérez-Sánchez, E., Oliveira, M., Recio, M., Tormo, R., Morales, J., 2013. Spatial and temporal distribution of Alternaria spores in the Iberian Peninsula atmosphere, and meteorological relationships: 1993-2009. Int. J. Biometeorology 57, 265-274.

Akhtar, N., Shoaib, A., Awan, Z.A., Amin, U., 2015. First report of Aspergillus parvisclerotigenusrot in garlic bulbs from Pakistan. Plant Dis. 99.

Ansari, T.U., Valsan, A.E., Ojha, N., Ravikrishna, R., Narasimhan, B., Gunthe, S.S., 2015. Model simulations of fungal spore distribution over the Indian region. Atmos. Environ. 122, 552-560.

Ballero, M., de Gioannis, N., Lombardini, S., Goretti, G., 1992. Comparative study about airborne spores in Cagliari and Perugia. Aerobiologia 8, 141-147.

Bowers, R.M., McLetchie, S., Knight, R., Fierer, N., 2011. Spatial variability in airborne bacterial communities across land-use types and their relationship to the bacterial communities of potential source environments. ISME J. 5, 601-612.

Clot, B., 1998. Forecast of the poaceae pollination in Zurich and Basle (Switzerland). Aerobiologia 14, 267-268.

Clot, B., 2001. Airborne birch pollen in Neuchâtel (Switzerland): onset, peak and daily patterns. Aerobiologia 17, 25-29.

Clot, B., 2003. Trends in airborne pollen: an overview of 21 years of data in Neuchâtel (Switzerland). Aerobiologia 19, 227-234.

Comtois, P., Alcazar, P., Néron, D., 1999. Pollen counts statistics and its relevance to precision. Aerobiologia 15, 19-28.

Corbaz, R., 1968. Spores in the athmosphere. Pathologia Microbiol. 32, 114-123.

Corden, J.M., Millington, W.M., Mullins, J., 2003. Long-term trends and regional variation in the aeroallergen Alternaria in Cardiff and Derby UK - are differences in climate and cereal production having an effect? Aerobiologia 19, 191-199.

Davies, R.R., 1969. Aerobiology and the relief of asthma in an alpine valley. Acta allergol. 24, 377-395.

Després, V.R., Huffman, J.A., Burrows, S.M., Hoose, C., Safatov, A.S., Buryak, G., Fröhlich-Nowoisky, J., Elbert, W., Andreae, M.O., Pöschl, U., 2012. Primary biological aerosol particles in the atmosphere: a review. Tellus B 64.

Docampo, S., Trigo, M.M., Recio, M., Melgar, M., García-Sánchez, J., Cabezudo, B., 2011. Fungal spore content of the atmosphere of the Cave of Nerja (southern Spain): diversity and origin. Sci. Total Environ. 409, 835-843.

Domínguez, E., Galán, C., Villamandos de la Torre, F., Infante, F., 1992. Handling and Evalution of the Data from the Aerobiological Sampling. Monografias REA 1. Dep. Biol. Veget. Ecol. UCO, Spain, pp. 1-13.

El-Akhdar, E.A., Ouda, S.M., 2009. Pathogenicity of different fungal isolates to the adult stage of the mediterranean fruit fly, Ceratitis capitata (Wiedmann). Egypt. J. Biol. Pest Control 19, 5-10.

Fernández-Rodríguez, S., Sadyś, M., Smith, M., Tormo-Molina, R., Skjøth, C.A., MayaManzano, J.M., Silva-Palacios, I., Gonzalo-Garijo, T., 2015. Potential sources of airborne Alternaria spp. spores in South-west Spain. Sci. Total Environ. 533, 165-176.

Fernández-Rodríguez, S., Tormo-Molina, R., Maya-Manzano, J.M., Silva-Palacios, I., Gonzalo-Garijo, T., 2014. Outdoor airborne fungi captured by viable and non-viable methods. Fungal Ecol. 7, 16-26.

Filali Ben Sidel, F., Bouziane, H., del Mar Trigo, M., El Haskouri, F., Bardei, F., Redouane, A., Kadiri, M., Riadi, H., Kazzaz, M., 2015. Airborne fungal spores of Alternaria, meteorological parameters and predicting variables. Int. J. Biometeorology 59, 339-346.

Flückiger, B., Koller, T., Monn, C., 2000. Comparison of airborne spore concentrations and fungal allergen content. Aerobiologia 16, 393-396.

Frei, T., 1998. The effects of climate change in Switzerland 1969-1996 on airborne pollen quantities from hazel, birch and grass. Grana 37, 172-179.

Frei, T., Leuschner, R.M., 2000. A change from grass pollen induced allergy to tree pollen induced allergy: 30 years of pollen observation in Switzerland. Aerobiologia 16, 407-416.

Frei, T., Torricelli, R., Peeters, A.G., Wüthrich, B., 1995. The relationship between airborne pollen distribution and the frequency of specific pollen sensitization at two climatically different locations in Switzerland. Aerobiologia 11, 269-273.

Gabey, A., Gallagher, M., Whitehead, J., Dorsey, J., Kaye, P., Stanley, W., 2010. Measurements and comparison of primary biological aerosol above and below a tropical forest canopy using a dual channel fluorescence spectrometer. Atmos. Chem. Phys. 10, 4453-4466.

Gabey, A., Stanley, W., Gallagher, M., Kaye, P.H., 2011. The fluorescence properties of aerosol larger than $0.8 \mu \mathrm{m}$ in urban and tropical rainforest locations. Atmos. Chem. Phys. 11, 5491-5504.

Gabey, A., Vaitilingom, M., Freney, E., Boulon, J., Sellegri, K., Gallagher, M., Crawford, I., Robinson, N., Stanley, W., Kaye, P.H., 2013. Observations of fluorescent and biological aerosol at a high-altitude site in central France. Atmos. Chem. Phys. 13, 7415-7428.

Galán, C., Smith, M., Thibaudon, M., Frenguelli, G., Oteros, J., Gehrig, R., Berger, U., Clot, B., Brandao, R., 2014. Pollen monitoring: minimum requirements and reproducibility of analysis. Aerobiologia 30, 385-395.

Grinn-Gofroń, A., 2011. Airborne Aspergillus and Penicillium in the atmosphere of Szczecin, (Poland) (2004-2009). Aerobiologia 27, 67-76.

Grinn-Gofroń, A., Bosiacka, B., 2012. The advanced statistical methods in aerobiological studies. Acta Agrobot. 65, 69-74.

Grinn-Gofron, A., Bosiacka, B., 2015. Effects of meteorological factors on the composition of selected fungal spores in the air. Aerobiologia 31, 63-72.

Grinn-Gofroń, A., Rapiejko, P., 2009. Occurrence of Cladosporium spp. and Alternaria spp. spores in Western, Northern and Central-Eastern Poland in 2004-2006 and relation to some meteorological factors. Atmos. Res. 93, 747-758.

Grinn-Gofroń, A., Strzelczak, A., Stępalska, D., Myszkowska, D., 2016. A 10-year study of Alternaria and Cladosporium in two Polish cities (Szczecin and Cracow) and relationship with the meteorological parameters. Aerobiologia 32, 83-94.

Gubler, C.C., Peeters, A.G., Wüthrich, B., 1994. Zur mykogenen Allergie: pilzsporengehalt in der Luft von Zürich 1984-1986. UCB Institute Allergy.

Haga, D.I., Burrows, S.M., Iannone, R., Wheeler, M.J., Mason, R.H., Chen, J., Polishchuk, E.A., Pöschl, U., Bertram, A.K., 2014. Ice nucleation by fungal spores from the classes agaricomycetes, ustilaginomycetes, and eurotiomycetes, and the effect on the atmospheric transport of these spores. Atmos. Chem. Phys. 14, 8611-8630.

Healy, D.A., O'Connor, D.J., Burke, A.M., Sodeau, J.R., 2012a. A laboratory assessment of the Waveband Integrated Bioaerosol Sensor (WIBS-4) using individual samples of pollen and fungal spore material. Atmos. Environ. 60, 534-543.

Healy, D.A., Huffman, J.A., O'Connor, D.J., Pöhlker, C., Pöschl, U., Sodeau, J.R., 2014. Ambient measurements of biological aerosol particles near Killarney, Ireland: a comparison between real-time fluorescence and microscopy techniques. Atmos. Chem. Phys. 14, 8055-8069.

Healy, D.A., O'Connor, D.J., Sodeau, J.R., 2012b. Measurement of the particle counting efficiency of the "Waveband Integrated Bioaerosol Sensor" model number 4 (WIBS4). J. Aerosol Sci. 47, 94-99.

Hernandez, M., Perring, A.E., McCabe, K., Kok, G., Granger, G., Baumgardner, D., 2016. Chamber catalogues of optical and fluorescent signatures distinguish bioaerosol classes. Atmos. Meas. Tech. 9, 3283-3292.

Hernández Trejo, F., Muñoz Rodríguez, A.F., Tormo Molina, R., Palacios, I.S., 2013. Airborne spores of basidiomycetes in Mérida (SW Spain). Ann. Agric. Environ. Med. 20, 657-663.

Herrero, A.D., Ruiz, S.S., Bustillo, M.G., Morales, P.C., 2006. Study of airborne fungal spores in Madrid, Spain. Aerobiologia 22, 135-142.

Herrero, B., Fombella-Blanco, M.A., Fernández-González, D., Valencia-Barrera, R.M., 1996. The role of meteorological factors in determining the annual variation of Alternaria and Cladosporium spores in the atmosphere of Palencia, 1990-1992. Int. J. Biometeorology 39, 139-142.

Huffman, J., Sinha, B., Garland, R., Snee-Pollmann, A., Gunthe, S., Artaxo, P., Martin, S., Andreae, M., Pöschl, U., 2012. Size distributions and temporal variations of biological aerosol particles in the Amazon rainforest characterized by microscopy and real-time UV-APS fluorescence techniques during AMAZE-08. Atmos. Chem. Phys. 12, 11997-12019.

Huffman, J., Treutlein, B., Pöschl, U., 2010. Fluorescent biological aerosol particle concentrations and size distributions measured with an Ultraviolet Aerodynamic Particle Sizer (UV-APS) in Central Europe. Atmos. Chem. Phys. 10, 3215-3233.

Irdi, G.A., R, J.J., White, C.M., 2010. Pollen and fungal spore sampling and analysis. Statistical evaluations. Grana 41, 44-47.

Kasprzyk, I., Worek, M., 2006. Airborne fungal spores in urban and rural environments in Poland. Aerobiologia 22, 169-176.

Kaye, P., Stanley, W., Hirst, E., Foot, E., Baxter, K., Barrington, S., 2005. Single particle multichannel bio-aerosol fluorescence sensor. Opt. express 13, 3583-3593.

Kim, Y.K., Saito, S., Xiao, C.L., 2015. Occurrence of fludioxonil resistance in Penicillium digitatum from citrus in California. Plant Dis. 99.

Lanier, C., Richard, E., Heutte, N., Picquet, R., Bouchart, V., Garon, D., 2010. Airborne molds and mycotoxins associated with handling of corn silage and oilseed cakes in agricultural environment. Atmos. Environ. 44, 1980-1986.

Leuschner, R., 1974. Luftpollenbestimmung in Basel während der Jahre 1969 und 1970 (mit Übersicht über die Methoden und Ergebnisse von Luftpollenuntersuchungen). Verh. Naturf Ges. Basel 84, 521-625.

Leuschner, R.M., Comparison between pollen counts at ground and at roof level in Basel (Switzerland). Aerobiologia 15, 143-147.

Leuschner, R.M., Boehm, G., 1981. Pollen and inorganic particles in the air of climatically very different places in Switzerland. Grana 20, 161-167.

Leuschner, R.M., Christen, H., Jordan, P., Vonthein, R., 2000. 30 years of studies of grass pollen in Basel (Switzerland). Aerobiologia 16, 381-391.

Leyronas, C., Halkett, F., Nicot, P.C., 2015. Relationship between the genetic characteristics of Botrytis sp. airborne inoculum and meteorological parameters, seasons and the origin of air masses. Aerobiologia 31, 367-380.

Maya-Manzano, J., Fernández-Rodríguez, S., Hernández-Trejo, F., Díaz-Pérez, G., Gonzalo-Garijo, Á., Silva-Palacios, I., Muñoz-Rodríguez, A., Tormo-Molina, R., 2012. Seasonal Mediterranean pattern for airborne spores of Alternaria. Aerobiologia 28, 
$515-525$.

Mensah-Attipoe, J., Saari, S., Veijalainen, A.M., Pasanen, P., Keskinen, J., Leskinen, J.T.T., Reponen, T., 2016. Release and characteristics of fungal fragments in various conditions. Sci. Total Environ. 547, 234-243.

Muñoz-Rodríguez, A., Silva-Palacios, I., Tormo-Molina, R., 2010. Influence of meteorological parameters in hourly patterns of grass (Poaceae) pollen concentrations. Ann. Agric. Environ. Med. 17, 87-100.

Muñoz-Rodríguez, A.F., Gonzalo-Garijo, M.A., González, J.F., Martínez, J.F., TormoMolina, R., Paredes, M.M., Silva-Palacios, I., 1996. Study of airborne fungal spores in the Badajoz area (Spain). Allergy 51 (31), 123 (Proceeding of the Annual Meeting of the European Academy of Allergology and Clinical Immunology, Budapest, Hungary).

Nikkels, A.H., Terstegge, P., Spieksma, F.T.M., 1996. Ten types of microscopically identifiable airborne fungal spores at Leiden, The Netherlands. Aerobiologia 12, 107-112.

Norros, V., Penttilä, R., Suominen, M., Ovaskainen, O., 2012. Dispersal may limit the occurrence of specialist wood decay fungi already at small spatial scales. Oikos 121, 961-974.

O'Connor, D., Healy, D., Sodeau, J., 2015. A 1-month online monitoring campaign of ambient fungal spore concentrations in the harbour region of Cork, Ireland. Aerobiologia 1-20.

O'Connor, D.J., Sadyś, M., Skjøth, C.A., Healy, D.A., Kennedy, R., Sodeau, J.R., 2014. Atmospheric concentrations of alternaria, cladosporium, Ganoderma and Didymella spores monitored in Cork (Ireland) and Worcester (England) during the summer of 2010. Aerobiologia 30, 397-411.

Oberle, M., Reichmuth, M., Laffer, R., Ottiger, C., Fankhauser, H., Bregenzer, T., 2015 Non-seasonal variation of airborne aspergillus spore concentration in a hospital building. Int. J. Environ. Res. Public Health 12, 13730-13738.

Oliveira, M., Ribeiro, H., Delgado, J.L., Abreu, I., 2009. Seasonal and intradiurnal variation of allergenic fungal spores in urban and rural areas of the North of Portugal. Aerobiologia 25, 85-98.

Organization.W.H, 2000. Guidelines for Concentration and Exposure-response Measurement of Fine and Ultra Fine Particulate Matter for Use in Epidemiological Studies. World Health Organization, Geneva.

Pakpour, S., Li, D.W., Klironomos, J., 2015. Relationships of fungal spore concentrations in the air and meteorological factors. Fungal Ecol. 13, 130-134.

Pasquarella, C., Balocco, C., Pasquariello, G., Petrone, G., Saccani, E., Manotti, P., Ugolotti, M., Palla, F., Maggi, O., Albertini, R., 2015. A multidisciplinary approach to the study of cultural heritage environments: experience at the Palatina Library in Parma. Sci. Total Environ. 536, 557-567.

Pepeljnjak, S., Klarić, M.Š, 2005. Seasonal variations of airborne fungi in continental and Mediterranean parts of Croatia. Period. Biol. 107, 351-355.

Perring, A.E., 2015. Airborne observations of regional variation in fluorescent aerosol across the United States. J. Geophys. Res. Atmos. 120, 1153-1170.

Pöhlker, C., Huffman, J., Poschl, U., 2012. Autofluorescence of atmospheric bioaerosolsfluorescent biomolecules and potential interferences. Atmos. Meas. Tech. 5, 37-71.

Pöhlker, C., Huffman, J.A., Förster, J.-D., Pöschl, U., 2013. Autofluorescence of atmospheric bioaerosols: spectral fingerprints and taxonomic trends of pollen. Atmos. Meas. Tech. 6, 3369-3392.

Pyrri, I., Kapsanaki-Gotsi, E., 2007. A comparative study on the airborne fungi in Athens, Greece, by viable and non-viable sampling methods. Aerobiologia 23, 3-15.
Pyrri, I., Kapsanaki-Gotsi, E., 2015. Evaluation of the fungal aerosol in Athens, Greece, based on spore analysis. Aerobiologia 31, 179-190.

Rodolfi, M., Lorenzi, E., Picco, A.M., 2003. Study of the occurrence of greenhouse microfungi in a Botanical Garden. J. Phytopathology 151, 591-599.

Rodriguez-Rajo, F.J., Iglesias, I., Jato, V., 2005. Variation assessment of airborne Alternaria and Cladosporium spores at different bioclimatical conditions. Mycol. Res. $109,497-507$.

Ruga, L., Orlandi, F., Romano, B., Fornaciari, M., 2015. The assessment of fungal bioaerosols in the crypt of St. Peter in Perugia (Italy). Int. Biodeterior. Biodegrad. 98, 121-130.

Sadyś, M., Skjøth, C.A., Kennedy, R., 2016. Forecasting methodologies for Ganoderma spore concentration using combined statistical approaches and model evaluations. Int. J. Biometeorol. 60, 489-498.

Salonen, H., Duchaine, C., Mazaheri, M., Clifford, S., Lappalainen, S., Reijula, K., Morawska, L., 2015. Airborne viable fungi in school environments in different climatic regions - a review. Atmos. Environ. 104, 186-194.

Schäppi, G.F., Monn, C., Wüthrich, B., Wanner, H.U., 1996. Analysis of allergens in ambient aerosols: comparison of areas subjected to different levels of air pollution. Aerobiologia 12, 185-190.

Schappi, G.F., Suphioglu, C., Taylor, P.E., Knox, R.B., 1997. Concentrations of the major birch tree allergen Bet v. 1 in pollen and respirable fine particles in the atmosphere. J. allergy Clin. Immunol. 100, 656-661.

Sindt, C., Besancenot, J.P., Thibaudon, M., 2016. Airborne Cladosporium fungal spores and climate change in France. Aerobiologia 32, 53-68.

Sun, Q., Wang, L., Lu, Z., Liu, Y., 2015. In vitro anti-aflatoxigenic effect and mode of action of cinnamaldehyde against aflatoxin B1. Int. Biodeterior. Biodegrad. 104, 419-425.

Suphioglu, C., Singh, M.B., Taylor, P., Bellomo, R., Holmes, P., Puy, R., Knox, R.B., 1992. Mechanism of grass-pollen-induced asthma. Lancet 339, 569-572.

Tomassetti, B., Lombardi, A., Cerasani, E., Di Sabatino, A., Pace, L., Ammazzalorso, D., Verdecchia, M., 2013. Mapping of alternaria and pleospora concentrations in central Italy using meteorological forecast and neural network estimator. Aerobiologia 29, 55-70.

Toprak, E., Schnaiter, M., 2012. Fluorescent biological aerosol particles (FBAPs) measured with the Waveband Integrated Bioaerosol Sensor WIBS-4: laboratory tests combined with a one year field study. Atmos. Chem. Phys. Discuss. 12, 17607-17656.

Tormo-Molina, R., Maya-Manzano, J.M., Fernández-Rodríguez, S., Gonzalo-Garijo, Á, Silva-Palacios, I., 2013. Influence of environmental factors on measurements with Hirst spore traps. Grana 52, 59-70.

Tormo-Molina, R., Muñoz-Rodríguez, A., Silva-Palacios, I., 1996. Sampling in aerobiology. Differences between traverses along the length of the slide in Hirst sporetraps. Aerobiologia 12, 161-166.

Twaroch, T.E., Curin, M., Valenta, R., Swoboda, I., 2015. Mold allergens in respiratory allergy: from structure to therapy. Allergy, Asthma Immunol. Res. 7, 205-220.

Varonier, H.S., 1969. Etude du potential aero-allergénique (pollinique et fongique) à Genève. Acta Allergol. 24, 410-420.

Vélez-Pereira, A.M., De Linares, C., Delgado, R., Belmonte, J., 2016. Temporal trends of the airborne fungal spores in Catalonia (NE Spain), 1995-2013. Aerobiologia 32, 23-37. 